\title{
SOR ANA DE LA CRUZ RIBERA (1606-1650) Y LA CAPILLA DEL PADRE DE FAMILIAS DEL CONVENTO DE SANTA CLARA DE MONTILLA (CÓRDOBA)
}

\author{
ELENA BELLIDO VELA \\ Universidad de Sevilla
}

\begin{abstract}
Resumen
La vinculación que se establece entre el marquesado de Priego y el convento de Santa Clara de Montilla queda reflejada, entre otras facetas, en la relevancia que adquirieron algunas de sus religiosas, las cuales pertenecieron o fueron cercanas a esta familia nobiliaria. Es el caso de sor Ana de la Cruz Ribera, sobrina de los V marqueses de Priego, cuya vida en religión destacó por su extraordinaria observancia y misticismo. Su devoción a la Pasión de Cristo quedó ejemplificada en una imagen de crucificado que le donó su hermano fray Payo Afán de Ribera, de la orden de San Agustín. En recuerdo a su santidad se construyó una capilla en la clausura del convento de las clarisas de Montilla, cuyo estudio artístico se expone en este trabajo.
\end{abstract}

\section{Palabras clave}

Sor Ana de la Cruz Ribera. Montilla. Convento de Santa Clara. Padre de Familias. Marquesado de Priego. III duque de Alcalá.

\section{SOR ANA DE LA CRUZ RIBERA (1606-1650) AND THE FAMILIES FATHER CHAPEL IN MONTILLA SANTA CLARA CONVENT.}

Abstract
The bond established between the marquisate of Priego and the convent of Saint Clara of Montilla is reflected, among other facets, in the relevance that acquired some of their nuns, who belonged or were close to this nobiliary family. This is the case of sister Ana de la Cruz Ribera, niece of the $\mathrm{V}$ marquises of Priego, whose life in religion was detached for her extraordinary observance and mysticism. Her devotion to the Passion of Chist was exemplified in an image of the crucified that was donated by her brother fray Payo Afán de Ribera, of the order of St. Augustine. In memory of her sanctity, a chapel in the cloister of the clarisas convent in Montilla was built.

$$
\text { Keywords }
$$

Sister Ana de la Cruz Ribera. Montilla. Saint Clara Convent. Marquisate of Priego. III duke of Alcalá. 
Desde su fundación en 1525 a instancias del marquesado de Priego, el convento de Santa Clara de Montilla ha quedado indisolublemente vinculado a esta importante familia nobiliaria ${ }^{1}$. Era gesto habitual entre la aristocracia de la época ejercer su patronazgo en beneficio de las comunidades conventuales, aspecto en el que podemos analizar distintos contenidos: religiosos, económicos, políticos..., que son difíciles de deslindar ${ }^{2}$. El generoso mecenazgo dispensado por los Fernández de Córdoba fue en extremo magnánimo desde los mismos inicios de su construcción, en los albores del siglo XVI, cuando el cabeza del linaje era Pedro Fernández de Córdoba, heredero legítimo del mayorazgo de la Casa de Aguilar y primer marqués de Priego desde 1501.

La relevante calidad artística que presenta el conjunto arquitectónico, así como la enorme extensión construida, nos permite apreciar el patrocinio absoluto que esta noble familia despliega en el monasterio de Santa Clara. En su edificación intervinieron artífices de reconocido prestigio, como lo fue Hernán Ruiz I - maestro mayor de la catedral y Obispado de Córdoba -, arquitecto al que se le atribuyen las obras del templo conventual y la realización de su espléndida portada ${ }^{3}$. Asimismo, son pródigas las excelentes piezas que componen el catálogo de bienes artísticos que atesoran la iglesia y las dependencias claustrales ${ }^{4}$. Fueron cuantiosas las pinturas, esculturas y obras de orfebrería que ingresaron merced a la piadosa voluntad de los miembros del marquesado de Priego, quienes perpetuaron una importante actividad benefactora desde sus inicios. Todo ello permite considerar al convento de Santa Clara de Montilla como una de las fundaciones franciscanas más importantes de Andalucía.

El elevado coste económico que suponía la financiación del proyecto conventual y su correspondiente amparo patrocinador no era cosa baladí. De esta forma, a cambio de las cuantiosas dádivas de las que el marquesado se desprendía, sus miembros recibían una serie de privilegios extraordinarios. Entre los mismos, y en lo que respecta al convento de Santa Clara, el más delator para el vecino de a pie era la licencia que la familia marquesal disponía para poder asistir a los oficios religiosos desde la tribuna - abierta ex profeso-, situada inmediata al presbiterio del templo monacal. De esta forma, los señores de Aguilar accedían a la misma a través de la galería que, dada su proximidad, conectaba la residencia palaciega con la iglesia conventual ${ }^{5}$.

La libertad de ingreso a las dependencias claustrales era otra de las prerrogativas que disfrutaban los marqueses, dado que algunos de ellos poseían bula papal que les permitía entrar sin impedimento alguno por parte de la prelatura conventual ${ }^{6}$. Santa Clara era un

1 La voluntad del I marqués de Priego fue que esta fundación conventual se destinase a acoger una comunidad de frailes de la orden de San Francisco, donde quedaría establecido el panteón familiar de la Casa de Aguilar. Según diversos testimonios de la época, la construcción pudo estar iniciada en 1512. Tres años después de la fecha señalada se constituyó la primera comunidad de frailes, pese a que las obras no estaban finalizadas. Una vez que Pedro Fernández de Córdoba fallece, en 1517, dos de sus hijas -Isabel Pacheco y María de Luna- deciden fundar un monasterio de clarisas en Montilla. Por este motivo Catalina Fernández de Córdoba, II marquesa de Priego, opta por modificar lo ordenado por su padre, y el convento que en un principio se levantó como morada de frailes seráficos fue destinado a acoger una comunidad de religiosas clarisas desde 1525, siendo sus fundadoras sor María Jesús de Luna y sor Isabel Pacheco, quien fue su primera abadesa. No obstante, para no contravenir los deseos de su progenitor, Catalina Fernández de Córdoba mandó construir, asumiendo su financiación, un nuevo convento destinado a los franciscanos, en cuyo templo se ubicaría el panteón familiar de los miembros del marquesado de Priego.

${ }^{2} \mathrm{La}$ iniciativa fundacional que protagonizaron los marqueses de Priego en las villas de sus dominios a lo largo de las centurias de la modernidad fue cuanto menos destacada. Cinco son las fundaciones acometidas en Montilla, al ser considerada capital del señorío, en Priego de Córdoba fueron dos, al igual que en Aguilar de la Frontera. Atienza López, 2008: 166-167; 2010: 235-269.

3 Garramiola, 1982: 134. Bernier Luque/Nieto Cumplido/Rivas Carmona/López Salamanca, 1993: 187.

${ }^{4}$ Ramírez Laguna/Bellido Vela: 2003.

${ }^{5}$ Bula de penitenciaría a favor de Catalina Fernández de Córdoba, marquesa de Priego, para poder unir su palacio al Convento de Santa Clara de Montilla mediante un puente, 7 de febrero de 1544. Archivo Ducal de Medinaceli, Sevilla (ADM), Priego, legajo, 13-17, s/f.

${ }^{6}$ Bula de penitenciaría favor de Catalina Fernández de Córdoba, marquesa de Priego, para entrar en el monasterio de Santa Clara de Montilla y quedarse a dormir en él, 27 de febrero de 1532. (ADM), Priego, legajo, 13-11, s/f. Breve de Gregorio XIII a Catalina Fernández de Córdoba, marquesa de Priego, para que ella y una 
ámbito habitual para los Fernández de Córdoba, quienes acudían con frecuencia al cenobio con el propósito de asistir a sus magníficos actos litúrgicos y de estar al corriente de su funcionamiento, pero también con el objeto de visitar a las religiosas pertenecientes a tan distinguido linaje y recibir asistencia espiritual.

No obstante, sería un error que nos limitásemos a enunciar el espléndido mecenazgo artístico proyectado por el marquesado de Priego en el convento de Santa Clara de Montilla como el principal vínculo que imbrica ambas instituciones. A su misma altura queda el enorme caudal espiritual y ejemplo de santidad que aportaron distinguidas mujeres vinculadas a la Casa de Aguilar, comenzando por las mismas fundadoras ${ }^{7}$, sor María Jesús de Luna y sor Isabel Pacheco, hijas del I marqués de Priego ${ }^{8}$. Constante y pródiga ha sido la presencia de religiosas pertenecientes o relacionadas con el linaje de los Fernández de Córdoba hasta bien entrado el siglo XVIII, algunas de las cuales llegaron a dirigir los designios del convento al ocupar el cargo de abbadesa in capite?

De la segunda mitad del siglo XVI destaca la estela dejada por sor Ana de la Cruz Ponce de León (1527-1601), condesa de Feria, fiel seguidora del Maestro Juan de Ávila, quien voluntariamente rehusó de todos sus bienes y privilegios para dedicarse a la vida contemplativa y rendir cuentas a Dios. Su reconocida virtud y observancia le hizo merecer el título de Venerable ${ }^{10}$. Desde su misma existencia, en las damas pertenecientes al marquesado de Priego estuvo presente el ejemplo observante de la Santa Condesa de Feria. Siguiendo sus virtuosas huellas encontramos a sor Ana de la Cruz Ribera (1606-1650), religiosa que ocupa el interés de esta aportación.

Las páginas que siguen se focalizarán en dos aspectos fundamentales, por un lado en el estudio de la trayectoria vital de sor Ana de la Cruz Ribera -antes y después de entrar en religión-, su ejemplar observancia y excepcional altura mística, virtudes de las que tenemos testimonio a través de los escritos que ella dejó. Para adentrarnos en su semblanza personal se ha seguido una fuente fundamental, como son las noticias ofrecidas por el cronista franciscano fray Alonso de Torres ${ }^{11}$, así como las procedentes de Garramiola Prieto ${ }^{12}$, que han sido contrastadas con nuevos datos que se han obtenido en distintos archivos y quedarán especificadas en su momento. No obstante, aunque la información del autor seráfico - que ha sido recogida sistemáticamente por otros autores sin más ${ }^{13}$ - aporta una contextualización histórica que no debemos perder de vista, se advierte un discurso panegírico ensalzador de las virtudes pías de la excelsa clarisa. Para su redacción, Torres hubo de tomar referencias muy cercanas y recientes, ya que la edición de su obra difiere en muy pocos años de la fecha del fallecimiento de la noble religiosa. En esta última dimensión hemos de señalar el afán que se advierte en el autor por manifestar un matiz hagiográfico de su persona, imbuido del espíritu contrarreformista del momento. Este interés puede entrañar su origen, asimismo, en los miembros del marquesado de Priego, deseosos de tener entre sus componentes o afines quien destacara por una excepcional santidad y, de esta forma, aumentar su consideración entre sus súbditos. Es precisamente en esta circunstancia donde contextualizamos la construcción de una capilla en memoria de la religiosa una vez que falleció, segundo aspecto

hija suya puedan entrar cuatro veces al año en el convento de Santa Clara de Montilla, 27 de abril de 1574. (ADM), Priego, legajo, 13-27, s/f. Torres, 1686:698.

7 Torres, 1683: 465. Graña Cid, 2011: 149-177. Ambos autores evocan las palabras de san Francisco de Borja, quien percibía un profundo aire de espiritualidad nada más cruzar el compás de Santa Clara de Montilla.

8 Sor Isabel de los Ángeles Pacheco entró como novicia en el convento de Santa Isabel de los Ángeles de Baza, donde profesa en 1513. Por su parte, sor María Jesús de Luna pasó el noviciado en el monasterio de Santa Clara de Andújar. Su profesión solemne tuvo lugar en el convento de Santa Clara de Montilla, el 12 de julio de 1525, fecha que se considera como la fundacional de este monasterio. Torres, 1683: 613-614, 659.

${ }^{9}$ Rodríguez de Gracia, 1988: 271.

${ }^{10}$ Sobre el personaje véase: Roa, 1615.

11 Torres, 1683: 679-711.

12 Garramiola, 1994. El autor abunda en la contextualización de la figura de sor Ana de la Cruz dentro del ámbito familiar del marquesado de Priego, además de ofrecer interesantes datos sobre la vida conventual en el transcurso de la existencia de dicha religiosa.

13 Ribera, 1679: s/f. Matute y Gaviria, 1997: 50-52. 


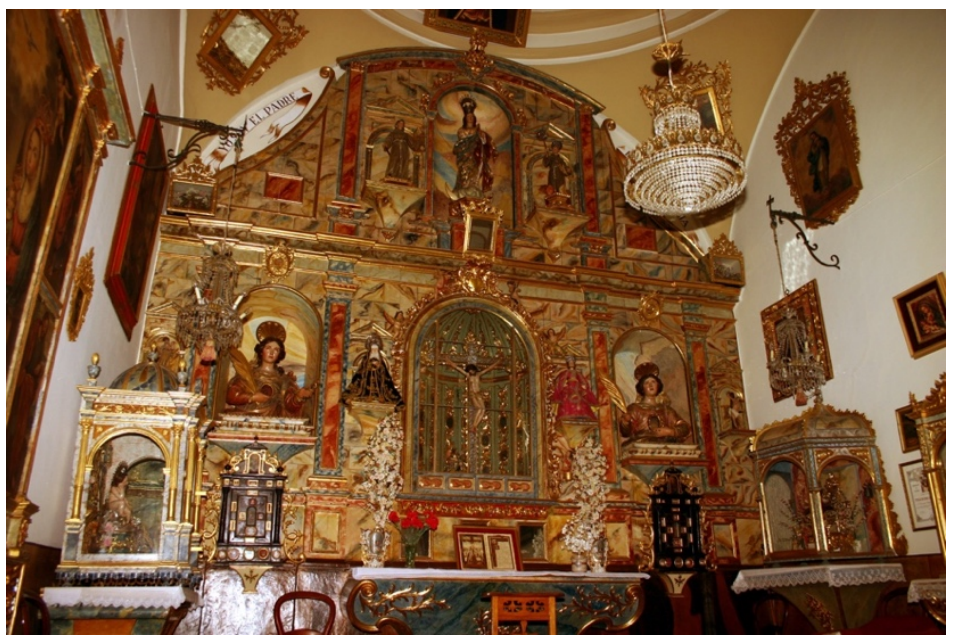

Fig. 1. Retablo mayor. Autora: Elena Bellido

Vela.

que se aborda en este trabajo. Aunque existen distintos trabajos que realizan una aproximación sobre sus bienes artísticos ${ }^{14}$, en estas páginas se ofrece una primera interpretación sobre el papel que ejerce sor Catalina de la Trinidad Fernández de Córdoba - hermana del VI marqués de Priego y, por tanto, valedora de la exaltación de santidad de sor Ana de la Cruz-como promotora de las artes en aras de la construcción de esta capilla. Asimismo se abordará un estudio estilístico e iconográfico de algunas de las piezas más emblemáticas de dicha capilla, constatando su vinculación con la célebre religiosa además de otros miembros del marquesado de Priego.

De esta forma, el objetivo de este trabajo centrará su atención en establecer una relación directa entre la figura de sor Ana de la Cruz Ribera con la capilla dedicada en su memoria, bajo la advocación de Padre de Familias. Para ello, partiendo de una exposición de su semblanza biográfica y de sus escritos, se establecerá su correspondencia con el lugar elegido para la construcción, así como con la iconografía de algunas de las piezas artísticas que contiene. La vinculación de esta capilla a través de sus obras no perderá de vista la aportación de los miembros del marquesado de Priego en su deseo de arropar el hálito de santidad que mostró sor Ana de la Cruz Ribera.

14 Torres, 1683: 461-462. Aunque sin extenderse ni emitir juicios de valor, contiene las primeras referencias sobre algunas de las piezas expuestas en la capilla, esclareciendo su origen y procedencia. Asimismo, el cronista ofrece datos interesantes en cuanto al estado de la capilla en el momento en el que inició el culto. Aguilar Jurado, A. (1776): Ulía ilustrada y fundación de Montilla. Historia de las dos ciudades, 1776. Montilla: [s.n.], ff. 262r-v. El autor ofrece una descripción, aunque sin abundar en datos históricos y de una manera muy generalizada, del contenido artístico de la capilla, exponiendo una relación de las obras más sobresalientes según su juicio. Morte Molina, 1982: 81-82. La información aportada en esta obra se nutre fundamentalmente de las descripciones efectuadas por Alonso de Torres y Aguilar Jurado, aunque encontramos ciertas aportaciones en cuanto a posibles autorías de obras. Garramiola, 1982: 134. En esta publicación se consideran las piezas que se encuentran en la capilla, aportando algunos datos novedosos en relación a su origen y posibles autorías, aunque no cita en ningún momento las fuentes en las que justifica tales atribuciones. Bernier Luque/Nieto Cumplido/Rivas Carmona/López Salamanca, 1993: 187. Aunque se basa en gran medida en la información emitida por los autores citados, aborda la descripción y valoración de las obras con cierto rigor, pero sin profundizar en aspectos iconográficos y plásticos. Ramírez Laguna/Bellido Vela, 2003. En este trabajo inédito se incluye el contenido de bienes artísticos del convento de Santa Clara para su inclusión en el Catálogo General de Patrimonio Histórico Andaluz. Bellido Vela, 2006: 23-57. En sus páginas se ofrece una primera aproximación al tema desarrollado en este trabajo. 


\section{Ana de ribera: la herencia del linaje}

Ana de Ribera pertenece a una de las estirpes aristocráticas más importantes y consolidadas de España durante el Siglo de Oro. Hija del III duque de Alcalá, Fernando Afán de Ribera, y de Leonor Manrique de Lara, nace en Sevilla el día 1 de enero de 1606, siendo bautizada en la parroquia de San Esteban ${ }^{15}$. En aquellos momentos la ciudad hispalense era el puerto de Indias, una de las principales metrópolis de Europa merced a la posesión del monopolio comercial establecido con América. Una ciudad a la que acudían los grandes mercaderes italianos y flamencos para concretar empresas mercantiles de gran envergadura. Ana pasó los primeros años de su infancia en la Casa de Pilatos. El palacio de los Enríquez de Ribera era entonces uno de los núcleos culturales más representativos de Sevilla. De refinados gustos artísticos, el III duque de Alcalá solicitó a Francisco Pacheco, en 1604, la decoración del techo del salón conocido como Gabinete Principal ${ }^{16}$. En esta ilustre estancia se dieron cita los eruditos, poetas, artistas y humanistas más destacados de la sociedad hispalense. Presididos por Fernando Afán de Ribera, en las célebres tertulias de la Casa de Pilatos eran habituales personalidades como el poeta Juan de Arguijo, el tratadista de arte y pintor Francisco Pacheco, el humanista Francisco de Medina y el erudito y artista cordobés Pablo de Céspedes entre otros, quienes se reunían asiduamente para departir sobre asuntos de contenido humanístico con altos vuelos intelectuales ${ }^{17}$.

La condición de hija natural del distinguido aristócrata sevillano determinó en gran medida los derroteros de la existencia de Ana de Ribera. De esta forma, cuando ella viene al mundo se estaban preparando los esponsales entre Alonso Fernández de Córdoba, V marqués de Priego, y Juana Enríquez de Ribera y Girón, hermana del duque de Alcalá y tía de la pequeña. Ambos nobles contraen matrimonio en febrero de 1607, año siguiente al de su nacimiento ${ }^{18}$.

Mientras duró su soltería, Juana Enríquez de Ribera se hizo cargo de la crianza de la niña Ana. No obstante, una vez que se instaló en Montilla como marquesa de Priego, la trajo consigo $^{19}$, contando entonces con poco más de tres años de edad. Además vinieron con la joven marquesa otras dos sobrinas, Leonor y María de Ribera, también hijas extramatrimoniales de su hermano, el III duque de Alcalá. Más tarde llegaría otra niña, llamada Juana.

\section{Infancia y juventud en el convento}

Aunque las hijas del III duque de Alcalá convivieron con los miembros de la Casa de Aguilar en su residencia palaciega de Montilla algo más de cuatro años, pronto se convino que lo mejor para ellas sería instalarlas en el convento de Santa Clara como educandas. Al

\footnotetext{
15 Torres, 1683: 680.

16 Valdivieso González, 1992: 115-118.

${ }^{17}$ López Torrijos, 1985: 129-137. Lleó Cañal: 1979:48-50. La citada autora realiza un excelente análisis del programa iconográfico perteneciente al Gabinete Principal, cuyo asunto escenifica la Apoteosis de Hércules, ideado por el erudito Francisco de Medina y ejecutado por Francisco Pacheco. La composición, que es abordada en distintos registros compartimentados, representa a los dioses de la Antigüedad identificados por sus atributos. Asimismo, como indica Lléo Cañal, las deidades se han relacionado con los asistentes habituales a las tertulias organizadas en la Casa de Pilatos. En lo que se refiere a los dioses Júpiter y Juno han sido relacionados con el III Duque de Alcalá y su esposa, Beatriz de Moura y Corte Real. Resulta interesante señalar que en la figura de Venus, la cual se representa girando su rostro sin poder apreciarse sus facciones con total nitidez, ha querido verse a Leonor Manrique de Lara. Fernando Afán de Ribera mantuvo con esta dama una relación extramatrimonial, fruto de la cual nacieron varios hijos: Payo Afán de Ribera, que llegaría a ser Virrey de Nueva España y Arzobispo de México, Ana, María, Leonor y Juana de Ribera, las cuales ingresaron como religiosas en el convento de Santa Clara de Montilla.

18 Fernández de Córdoba, 1954: 184. Obra original manuscrita hacia 1620. Fernández de Bethencourt, 1905: 210

19 Torres, 1683: 680 .
} 
Fig. 2. Anónimo. Padre de Familias. Autora: Elena Bellido Vela.

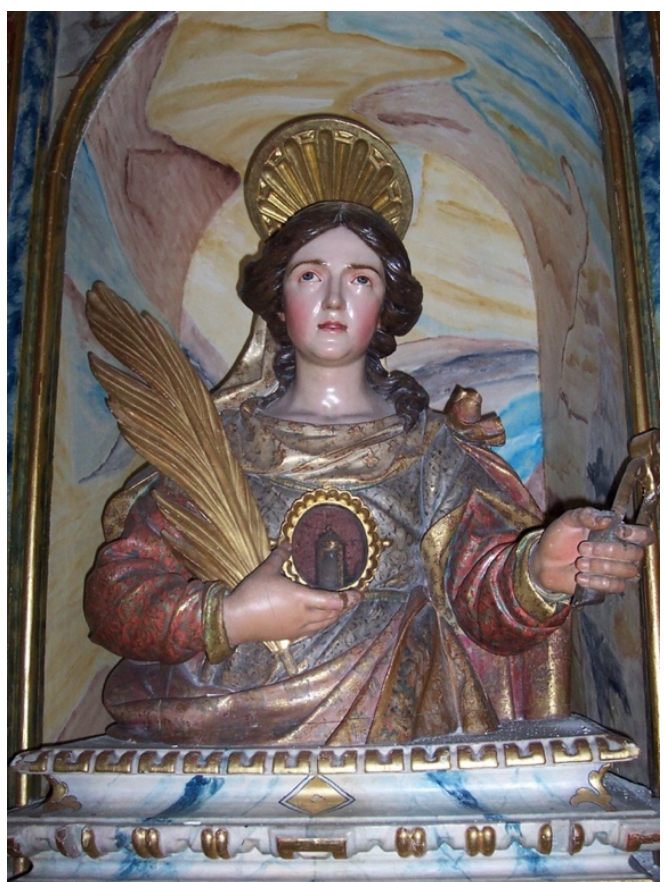

respecto hay que señalar que en algunos conventos femeninos se admitieron niñas como pupilas, generalmente procedentes de familias nobiliarias, que recibían lecciones de formación instructiva y de doctrina ${ }^{20}$, como es el caso de las hijas de los marqueses de Priego $^{21}$. Se conoce el expediente que contempla la autorización que el ministro provincial de los frailes de la regular observancia de San Francisco y consultor del Santo Oficio, Juan Ramírez, concede a Ana, Leonor y María de Ribera para proceder a su ingreso, siendo menores de edad, en el convento de Santa Clara. Este documento está rubricado en el convento de San Francisco de Granada, con fecha 13 de agosto de $1613^{22}$. Unos días después, el 17 del mismo mes y año, se constata el pago de dote de las referidas hijas del duque de Alcalá para ingresar en el convento clariano ${ }^{23}$.

Entre galerías claustrales y un fervoroso ambiente de oración, las hijas de Fernando Afán de Ribera recibieron de las monjas clarisas una educación esmerada y culta, dentro de un marco adecuado para que adquirieran una sólida formación tanto humanística como religiosa, en consonancia con el estamento privilegiado al que pertenecían. A pesar de que ingresaron a corta edad, Ana contaba con siete años - como queda constatado en los citados documentos-, las educandas llevarían hábito monjil y habrían de aceptar los preceptos establecidos por la gloriosa Santa Clara.

Pero lo que en un principio resultó ser una airosa salida para solventar la instrucción y custodia de las sobrinas de la V marquesa de Priego, acabó siendo el testimonio del más fiel ejemplo de santidad y observancia. Las hijas del duque de Alcalá profesaron como religiosas

20 Atienza López, 2010: 247.

${ }^{21}$ Licencia del nuncio provincial de Andalucía para que entrasen en el monasterio de Santa Clara de Montilla María y Juana de Córdoba, hijas del marqués de Priego, manteniendo hábito seglar, 26 de septiembre de 1618. Sevilla (ADM), Priego, legajo, 13-33, s/f. Fernández de Bethencourt, 1905: 214. El autor constata que, además de las documentadas, otras hijas del V marqués de Priego, Catalina María Fernández de Córdoba y sus hermanas Inés y Francisca, también ingresaron como educandas en el convento de Santa Clara de Montilla.

${ }^{22}$ Expedientes de monjas del siglo XVII, 13 de agosto de 1613. Archivo del Convento de Santa Clara, Montilla (ACSCM), s/f.

${ }^{23}$ Pago de dote de Ana, Leonor y María de Ribera, hijas de Fernando Afán de Ribera, III duque de Alcalá, 17 de agosto de 1613. Archivo de Protocolos, Montilla (APM), Juan Díaz de Morales, s/f. 


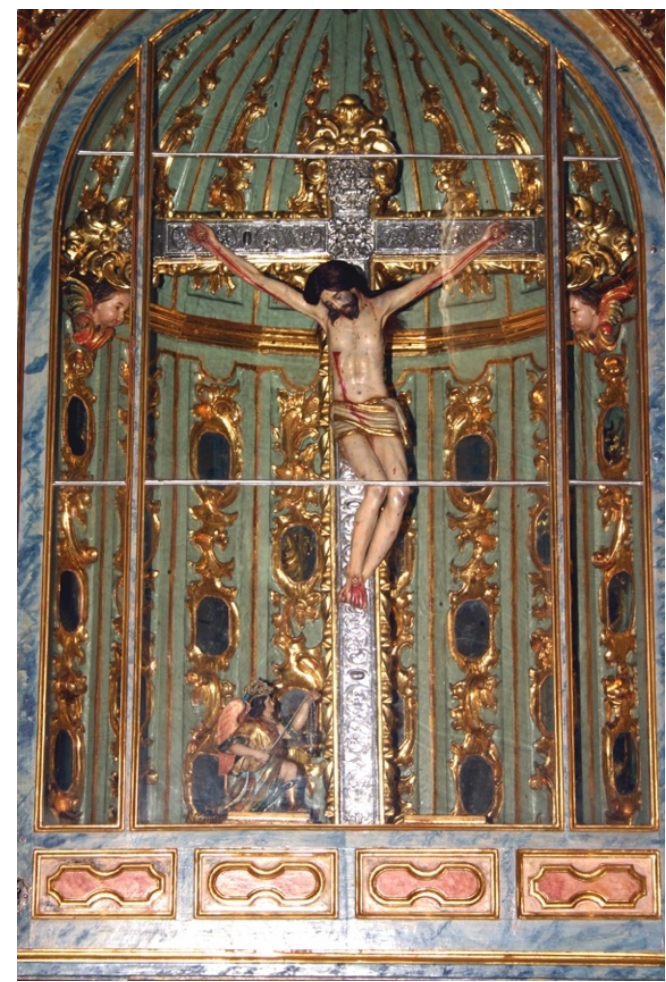

Fig. 3. Pedro Roldán. Santa Apolonia. Autora: Elena Bellido Vela.

clarisas $^{24}$, dejando una reconocida estela de virtud y observancia evangélica, especialmente Ana.

El historiador seráfico fray Alonso de Torres, en su celebérrima obra Crónica Franciscana de la Provincia de Granada, impresa en 1683, nos ofrece una semblanza biográfica de Ana de Ribera bastante cercana, no exenta de la intensa espiritualidad del momento en el que fue redactada ${ }^{25}$. Este autor, al igual que otras fuentes consultadas ${ }^{26}$, concede a su temprana vocación una justificación consignada por la divinidad, pareciendo estar destinada a la vida religiosa desde su mismo nacimiento, «en aquella pequeña edad tenía grandes ansias por ser santa, sin gustar de juegos, y entretenimientos. Tres horas de oración puesta de rodillas tenía todos los días, y algunas veces eran más» ${ }^{27}$. El carácter providencial de la precoz vocación de la futura clarisa queda refrendado a través de ejemplos y vivencias que tuvo en su infancia y juventud, marcados por una incuestionable altura humana y espiritual.

El día 1 de enero de 1621, contando entonces con 15 años de edad, Ana de Ribera ingresó en el noviciado. Un año después, y tomando como nombre en religión el de sor Ana de la Cruz, celebró su profesión solemne el día 8 de enero de $1622^{28}$. Su vida estuvo marcada por

${ }^{24}$ Expedientes de monjas del siglo XVII. Documentación referente a las hijas del Excmo. Sr. Fernando Enríquez de Ribera, duque de Alcalá. (ACSCM), s/f. Este documento registra las fechas de ingreso en el noviciado y profesión solemne de las hijas del III duque de Alcalá. Ana de Ribera, en religión sor Ana de la Cruz, accedió al noviciado el 1 de enero de 1621, y profesó el 8 d enero de 1622; Leonor de Ribera, en religión sor Clara de Cristo, ingresó como novicia el 1 de febrero de 1622, haciendo su profesión el 29 de marzo de 1623; María de Ribera, en religión sor María de la Asunción, entró en el noviciado el 15 de agosto de 1525, realizando profesión el 1 de septiembre de 1526; Juana de Ribera, en religión sor Juana de la Concepción, comenzó el noviciado en marzo de 1627, profesando en mayo de 1628.

25 Torres, 1683: 680-711.

26 Ribera, 1679: s/f. En esta obra se incluye la Carta del Ldo. Fernando García Muñoz, comisario del Santo Oficio de la Inquisición, en que da cuenta y noticia al Ilustrísimo Señor Obispo de Córdoba de lo que resultaba de las informaciones jurídicas de la santa vida y muerte de la V. Ana de la Cruz Ribera, 1664. Matute y Gaviria, 1997: 50-52.

27 Torres, 1683: 682.

${ }^{28}$ Expedientes de monjas del siglo XVII. Documentación referente a las hijas del Excmo. Sr. Fernando Enríquez de Ribera, duque de Alcalá. (ACSCM), s/f. 
una excepcional observancia, caridad, pobreza y humildad. Fue precisamente durante su existencia cuando la comunidad de clarisas de Montilla logra uno de los momentos de mayor fuerza espiritual.

\section{Vida en religión: sus escritos}

Cuando sor Ana de la Cruz decidió ofrecer su vida a Dios gozaba de una extraordinaria religiosidad, virtud que forjó su personalidad junto con una amplia formación humanística. Era mujer cultivada, de ingenio agudo y razón, como relata Alonso de Torres ${ }^{29}$. También avanza el cronista seráfico sus conocimientos de latín, su aventajada en retórica y grandes dotes en escritura, disciplinas que hubo de recibir durante su periodo de formación en el convento.

Las inquietudes místicas de la joven religiosa le encauzaron a profundizar en el estudio de las Sagradas Escrituras, logrando una especial habilidad y dominio en su exégesis. Asimismo, la música constituyó otra de sus predilecciones. Sor Ana de la Cruz Ribera tañía con maestría el arpa y la vihuela, llegando a componer piezas para órgano, que ella misma se encargaba de interpretar en los oficios divinos ${ }^{30}$.

La intensa espiritualidad que se respiraba en el convento de Santa Clara durante el transcurso de su vida quedó correspondida con el considerable aumento de religiosas que ingresaron en el mismo ${ }^{31}$, así como en las manifestaciones artísticas que a la par se introdujeron, bien por dotes o mediante adquisición. Fue precisamente en estos años que nos abren el paso a la plenitud del siglo XVII cuando las sobrias trazas del edificio conventual son ornamentadas con elementos que, tanto por su forma como por su mensaje catequético, permiten introducirnos en el más puro arte del barroco de matiz contrarreformista.

Gran parte de la aportación de estas novedades artísticas en el convento de Santa Clara se debieron al ingente mecenazgo alentado por sor Catalina de la Trinidad Fernández de Córdoba, hija de los $\mathrm{V}$ marqueses de Priego y, por tanto, prima hermana de sor Ana de la Cruz. Sor Catalina de la Trinidad ocupó el cargo de abadesa durante buena parte de los años centrales del siglo XVII, conviviendo algunos de los mismos con la ejemplar religiosa. Su prelatura constituye uno de los capítulos más brillantes de este monasterio en lo que se refiere a las aportaciones de bienes artísticos que se advierte en el mismo. En efecto, fue esta ilustre religiosa quien tomó la decisión de crear las devotas capillas del claustro principal, dedicadas a la Virgen, cuajadas de un barroquismo absoluto. Asimismo, durante su mandato ingresaron obras de arte ejecutadas por encumbrados maestros del setecientos, como Cornelio Schult, Juan de Valdés Leal o Pedro Roldán, algunas de las cuales hubo de conocer sor Ana de la $\mathrm{Cruz}^{32}$.

Si hubo alguien que entendió el camino que Dios guiaba a la hija del III duque de Alcalá fue fray Cristóbal del Viso, su confesor espiritual durante los últimos cuatro años de su vida ${ }^{33}$. Pronto advirtió el docto franciscano no sólo la sólida formación literaria que ella poseía, sino la amplitud espiritual que la embargaba. Fue por ello que el fraile seráfico le solicitó que dejara por escrito sus vivencias y reflexiones religiosas, las revelaciones que gozó y las profecías que vislumbró ${ }^{34}$.

Se trata de una serie de documentos manuscritos organizados en seis cuadernos y varios legajos sueltos ${ }^{35}$, los cuales se configuran como la principal fuente documental que

29 Torres, 1683: 687.

30 Torres, 1683: 684-687.

31 Torres, 1683, 467. En el momento de la redacción de esta obra se contabilizan 53 monjas profesas.

32 Bellido Vela, 2009: 41-57.

33 Torres, 1683: 691. El autor indica que fray Cristóbal del Viso fue designado confesor de sor Ana de la Cruz en 1646.

34 Triviño Monrabal, 1994: 39-45. Especializada en escritoras franciscanas hispanas, la autora realiza un primer estudio y transcripción de la obra literaria de sor Ana de la Cruz Ribera, captando su grandeza de espíritu.

${ }^{35}$ Escritos de sor Ana de la Cruz Ribera, 1646-1649. (ACSCM), s/f. 


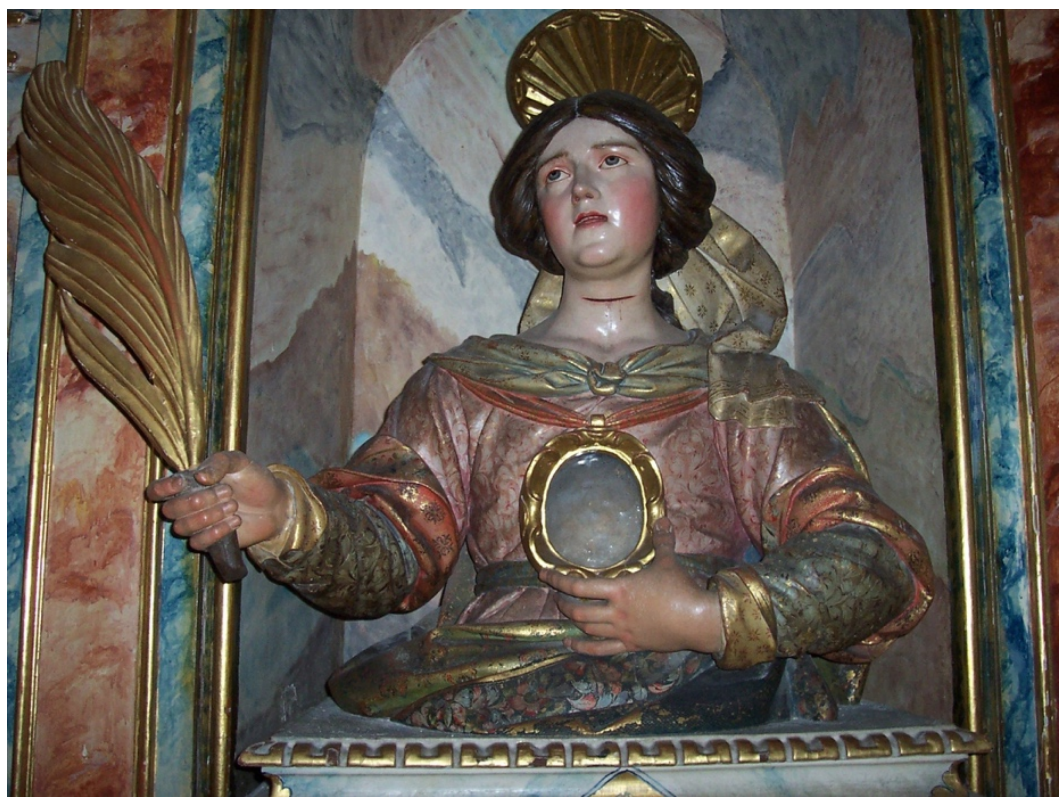

Fig. 4. Pedro Roldán. Santa Cecilia. Autora: Elena Bellido Vela.

disponemos para conocer la altura mística que alcanza sor Ana de la Cruz Ribera. El texto está tratado con género autobiográfico, mostrando una estructura clara y ordenada. Como señala Triviño Monrabal ${ }^{36}$, en su redacción utiliza un lenguaje directo y muy sentido, pudiendo advertir su auténtica vocación, su pensamiento piadoso y un estricto sentido de la obediencia en su conducta, aspectos que nos permiten adentrarnos en su espiritualidad de una manera transparente. Sin duda, dichos escritos constituyen la fuente de información más directa y certera para acercarnos su excepcional personalidad religiosa ${ }^{37}$.

A través de estos textos conocemos de primera mano la vida de penitencia que llevaba la devota monja. Duras vigilias, sacrificados ayunos y una estricta frugalidad alimenticia eran habituales a diario. Su vida en soledad se acentuó más si cabe cuando, a los 22 años, pierde la facultad auditiva. Si hubo algo que sor Ana de la Cruz lamentó profundamente fue el tener que abandonar su participación en la música de los divinos oficios ${ }^{38}$. No obstante, al respecto expresa que, «Iba conociendo que era grande estar sorda para tratar con Dios sin ruido ni estorbo de criaturas» ${ }^{39}$. La privación de oído contribuyó sobremanera en su deseado aislamiento, sumergiéndose en una afanosa búsqueda de Dios, de quien, sin embargo, escucha su voz entre el absoluto silencio que la rodeaba. A partir de este momento gozó en incontables ocasiones de la aparición de Cristo en su Pasión y Muerte, a quien dispensó una auténtica devoción. Estos prodigios no pasarán al olvido merced a su representación en algunos de los retratos que le dedicaron tras su fallecimiento.

Los continuos ayunos y tormentos a los que se sometía debilitaron considerablemente su salud, haciéndola cada vez más frágil. A los 35 años le diagnosticaron mal de perlesía,

\footnotetext{
36 Triviño Monrabal, 2005: 104.

${ }^{37}$ Se trata de la principal fuente documental que ha permitido conocer la personalidad religiosa de sor Ana de la Cruz Ribera. La semblanza biográfica elaborada por fray Alonso de Torres se nutre del texto que la misma religiosa nos legara acerca de su vida. Triviño Monrabal, 1994. Garramiola Prieto, 1994. El autor, aunque aporta nuevos datos sobre de sor Ana de la Cruz, el acercamiento que realiza a sus escritos es escaso.

38 Torres, 1683:685-686.

39 Triviño Monrabal, 1994:58.
} 
Fig. 5. Anónimo. Sor Ana de la Cruz Ribera. Autora: Elena Bellido Vela.

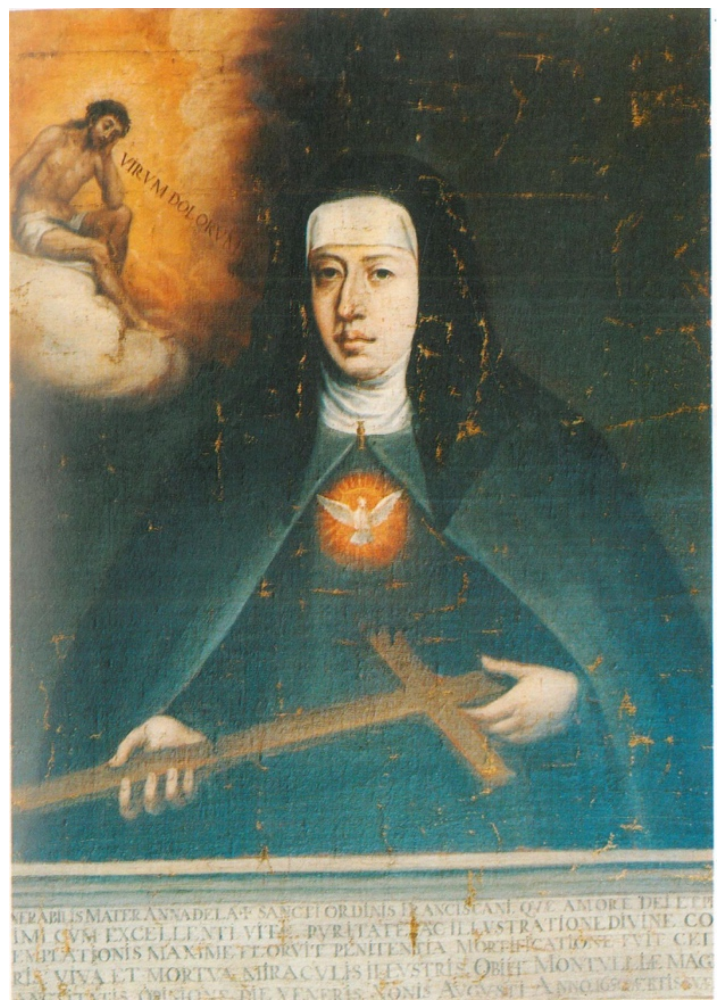

ocasionándole inmovilidad en las extremidades inferiores ${ }^{40}$. Los fuertes dolores que le produjo esta enfermedad, agravados por la sordera y sus continuas mortificaciones, fueron interpretados por la religiosa de manera gozosa. De esta forma, ella identificó el sufrimiento físico que padecía con un fervoroso deseo de cargar con la cruz de la enfermedad, de subir a la cruz y morir crucificada. La redacción de sus vivencias religiosas hubo de realizarse en una situación bastante difícil, dado que se encontraba impedida de movilidad y pasaba gran parte del tiempo en la enfermería conventual. Al carecer de fuerza para escribir, Triviño Monrabal indica que sus últimos dictados fueron recogidos por sor Catalina de la Trinidad Fernández de Córdoba ${ }^{41}$.

Fueron tres las crucifixiones que sor Ana de la Cruz Ribera advirtió durante los años que se alargó su enfermedad, concretamente en los años $1641^{42}, 1647^{43}$ y $1649^{44}$. Se trata de duros momentos en los que alcanzó un enorme dolor físico debido a la progresiva inmovilización que padecía en sus manos y piernas. Sufrimiento que soportó resignadamente, puesto que lo identificaba de manera análoga a los clavos de Cristo que la traspasaba, como si su cuerpo, miembro por miembro, fuese enclavado en el sagrado Madero ${ }^{45}$.

De esta manera, ella encontró en el incremento de su padecimiento una mayor fuerza en su unión y comunión absoluta con Dios. Constantes fueron las visiones en las que Jesús se le apareció en los momentos de la Pasión, trazándole su camino de santidad a través de gloriosas virtudes: la pobreza, el conocimiento interior, la obediencia, la humildad, el silencio y la tolerancia. Sin duda, la redacción de las vivencias religiosas que sintió durante los años que

40 Torres, 1683: 690.

41 Triviño Monrabal, 1994: 158. Cruz.

42 Torres, 1683:690. El autor indica que este hecho tuvo lugar el día 3 de mayo, día de la Invención de la

43 Torres, 1683:696. Según el cronista «Empeçó el día de la Cruz de Mayo, y acabó el de la de Setiembre».

44 Torres, 1683: 701.

45 Torres, 1683: 696. 


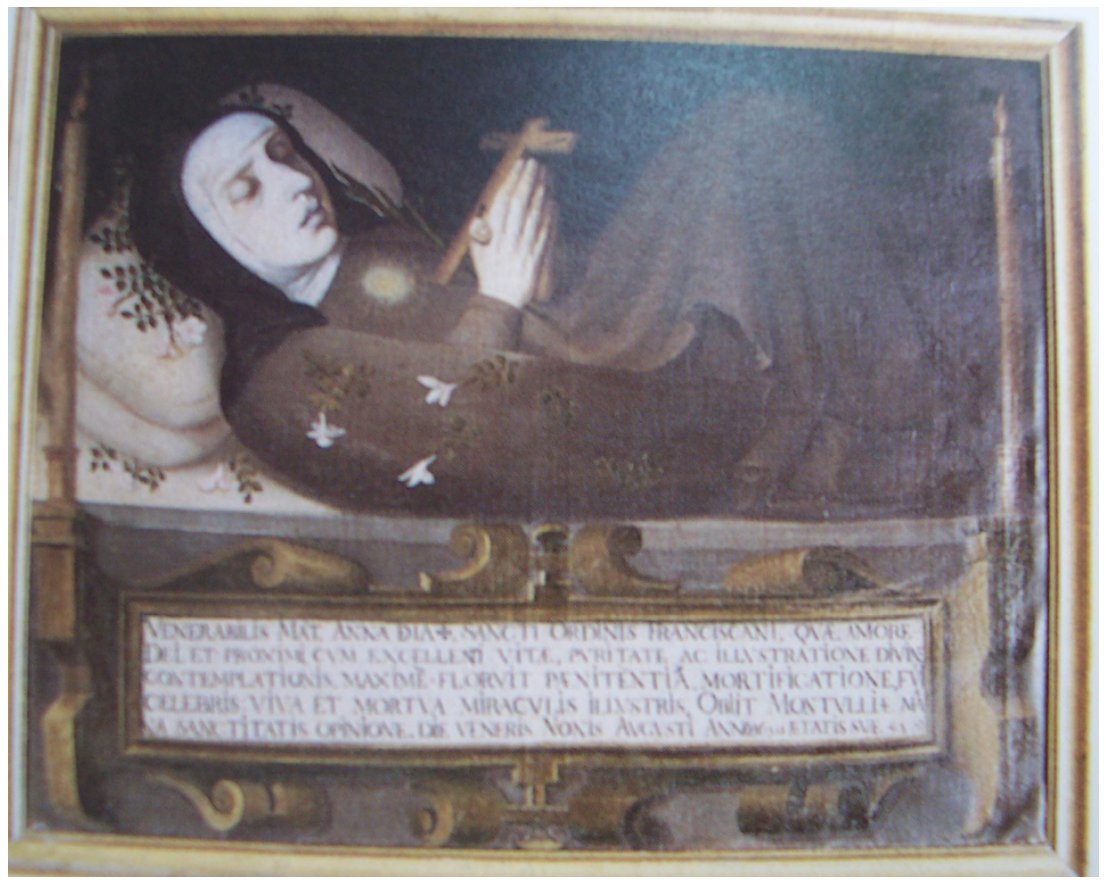

Fig. 6. Atribuido a Fray Pedro de Valderrama. Sor Ana de la cruz difunta. Autora: Elena Bellido Vela.

perduró su enfermedad fueron las que alcanzaron un mayor contenido espiritual y místico, que narró a través de su ferviente pluma.

\section{Hechos milagrosos}

La fama de santidad que sor Ana de la Cruz Ribera adquirió entre las religiosas de la comunidad de Santa Clara durante los últimos años de su vida pronto fue advertida entre los miembros de la Casa de Aguilar. Apenados los VI marqueses de Priego, Luis Ignacio Fernández de Córdoba Figueroa y Mariana Fernández de Córdoba Cardona y Aragón, debido a su falta de descendencia tras ocho años de matrimonio, solicitaron a la ejemplar religiosa - que era prima hermana del noble heredero-, para que rogara y se consumara este propósito ${ }^{46}$. Sin duda, las súplicas que Sus Excelencias le trasmitieron fueron escuchadas por el Altísimo y por san Luis Obispo de Toulouse, santo franciscano al que la religiosa le recomendó que dirigieran sus oraciones y tomasen por su Abogado. En efecto, al año siguiente, el de 1650, vino al mundo el que vendría a ser sucesor del marquesado de Priego, Luis Mauricio Fernández de Córdoba Figueroa, el primero de una dilatada parentela que aumentó hasta diez ${ }^{47}$. En acción de gracias al santo francés por su intercesión, los marqueses mandaron construir una capilla junto al palacio, bendecida bajo la advocación de San Luis Obispo $^{48}$, que actualmente se mantiene, y es conservada por las Hermanas Terciarias Franciscanas del Rebaño de María.

La elevada virtud de la que gozaba la sierva de Dios durante los momentos más duros de su enfermedad también fue conocida por los habitantes de Montilla. Precisamente en estos momentos, en el arco de tiempo que se prolonga entre 1648 y 1650, tuvo lugar una terrible epidemia que atacó gran parte del sur peninsular, diezmando sensiblemente su población.

\footnotetext{
46 Torres, 1683: 699-701.

${ }^{47}$ Fernández de Córdoba, 1954: 184. Fernández de Bethencourt, 1905: 218-221.

48 Torres, 1683:701.
} 
Montilla no se salvó del contagio y, junto a las cautelosas medidas sanitarias que acordaron los miembros del Concejo municipal ${ }^{49}$, la piedad popular se aferró a la ansiada intercesión divina.

Teniendo como escenario esta desoladora situación, sor Ana de la Cruz tuvo diversas apariciones. En el transcurso de estos arrebatos místicos ofreció a Jesucristo unas sencillas cruces de madera con la intención de que las bendijera y, posteriormente, fuesen repartidas a quien las solicitase para bien y utilidad de las almas ${ }^{50}$. Pronto se divulgó entre la población la fuerza milagrosa que gozaban las cruces de la noble clarisa. Fueron numerosos los que se acercaron al recinto conventual para recibir la imposición de una de estas cruces, dispensándoles gran veneración debido a su poder sanador y la concesión de indulgencias ${ }^{51}$.

La quebrantada salud que la acuciaba anunciaba su muerte, acaecida el día 5 de agosto de 1650, contando con tan sólo 44 años de edad y 37 de vida religiosa. Se cuenta que su fallecimiento conmocionó a los vecinos de Montilla, cientos de los cuales se acercaron hasta el convento clariano para darle una última despedida durante las treinta horas que su cuerpo estuvo sin enterrar. Aquellos que fueron pudieron tocar su rosario y obtener una reliquia de su hábito. Mariana Fernández de Córdoba se encargó disponer un solemne funeral, siendo enterrada en la capilla de la Asunción del Coro Bajo ${ }^{52}$.

La fama de santidad que le concedieron sus milagros pronto se propagó tanto en Montilla como fuera de ésta. Por ello, de orden de Juan Francisco Pacheco, Obispo de Córdoba, se hicieron informaciones jurídicas de la santa vida y muerte de la Venerable Ana de la Cruz Ribera ante el Licenciado Fernando García Muñoz, comisario del Santo Oficio. Se estimaron como verdaderos los testimonios aportados por un centenar de testigos interrogados, que fueron remitidos a la Sagrada Congregación de Ritos de Roma, para la causa de su beatificación, proceso que finalizó en el 20 de marzo de $1664^{53}$.

\section{Capilla del padre de familias}

El halo de santidad que desprendió la personalidad de sor Ana de la Cruz Ribera en la comunidad de Santa Clara no quedó olvidado tras su muerte. Lejos de ello, las religiosas pronto decidieron perpetuar su memoria mediante la construcción de una capilla expresamente dedicada a su recuerdo. El lugar elegido para tal propósito quedó acotado dentro del espacio que ocupó la antigua enfermería conventual, justamente donde la excelsa clarisa pasó su enfermedad y tuvo lugar su óbito.

La capilla comenzó a ejecutarse durante la prelatura de sor Catalina de la Trinidad Fernández de Córdoba ${ }^{54}$. Como se ha señalado en líneas anteriores, esta abadesa desempeñó una ingente actividad de promoción de las artes durante su mandato, que se prolongó hasta el año 1676, año en el que fue relevada por sor Inés de San Antonio ${ }^{55}$, hermana de la anterior y que, presumiblemente, continuó el proyecto iniciado. El nombre que en un principio se concedió a este recinto sagrado fue el de oratorio del Calvario o de Sor Ana de la Cruz

${ }^{49}$ Calvo Poyato, 1987: 131-132.

${ }^{50}$ Ribera, 1679: s/f. En esta obra, que posee un destacado contenido doctrinal y con aprobación eclesiástica, el autor defiende nueve proposiciones en que la V. Ana de la Cruz dejó propuestas las gracias que dijo haberse servido Nuestro Señor Jesucristo de conceder unas cruces, afirmando que su Majestad divina se dignó de darles su sagrada bendición.

51 Torres, 1683:702.

52 Torres, 1683:704.

${ }^{53}$ Ribera, 1679: s/f. Torres, 1683: 681. Matute y Gaviria, 1997:51

54 Sor Catalina de la Trinidad Fernández de Córdoba ocupó el cargo de abadesa hasta 1676. Esta fecha nos induce a pensar que la capilla dedicada a Sor Ana de la Cruz pudo proyectarse durante su gobierno, puesto que la obra de Alonso de Torres, editada en 1683, hace referencia a la misma. Véase: Torres, 1683:461-462.

55 Nombramiento de sor Inés de San Antonio como abadesa del convento de Santa Clara de Montilla tras el deceso de sor Catalina Margarita de la Trinidad Fernández de Córdoba, 6 de diciembre de 1676. (ACSCM), $\mathrm{s} / \mathrm{f}$. 
Ribera $^{56}$, aunque con el tiempo la devoción popular ha perpetuado la advocación del Padre de Familias, por la imagen del crucificado que lo preside.

Desde el punto de vista arquitectónico, la capilla del Padre de Familias dispone de planta cuadrangular y ocupa un espacio de $48 \mathrm{~m}^{2}$, estando cubierta por una bóveda encamonada con forma elíptica lisa sobre pechinas. En el lateral derecho se inserta un sencillo edículo rectangular que rememora el lugar exacto donde sor Ana de la Cruz estuvo en cama y tuvo lugar su muerte. Es de una extraordinaria belleza la solería, a base de losas vidriadas en tonos verde y blanco. Aunque su construcción se inició durante la segunda mitad del siglo XVII, se realizaron algunas reformas ya entrado el XVIII ${ }^{57}$.

La capilla del Padre de Familias puede considerarse como uno de los espacios del recinto conventual que gozan de una mayor fuerza espiritual. Cuajada de obras de arte y sentimiento místico, este lugar nos adentra de manera prodigiosa en la religiosidad y mensaje que trasmitió sor Ana de la Cruz Ribera. Por su contenido y su programa iconográfico, se concibe como un auténtico relicario consagrado a la noble clarisa.

En adelante se expondrá un estudio que se centrará en una selección de piezas artísticas pertenecientes a esta capilla. Debido a la ingente cantidad de obras que custodia, nos detendremos únicamente en aquellas que tienen una mayor entidad artística, así como en las que merecen una especial atención debido a su vinculación o valor documental con la figura de sor Ana de la Cruz Ribera ${ }^{58}$.

\section{Retablo mayor}

Sus líneas constructivas responden a esquemas neoclásicos de finales del siglo XVIII ${ }^{59}$. De un marcado clasicismo y claridad compositiva, el retablo se adapta a la curvatura del muro que configuran las pechinas de la bóveda. Está ensamblado en madera y policromado simulando jaspeados en tonos rojo, azul y blanco (fig.1).

El cuerpo principal se estructura en tres calles mediante pilastras cajeadas de orden toscano, adquiriendo la central de una mayor anchura. Ello le permite cobijar una hornacina de medio punto acristalada, que se constituye como centro focal del retablo y lugar donde se encuentra la sagrada imagen del Padre de Familias. En las calles laterales destacan los bustos relicarios de Santa Apolonia y Santa Cecilia, bajo los cuales es interesante señalar la presencia de respectivos relicarios de caoba, trabajados con una primorosa labor de taracea. Por su parte, el ático del retablo se concibe como una prolongación de la calle central, estando presidido por una hornacina en la que se halla una escultura dedicada a la Purísima. Los laterales del ático presentan sendos aletones con volutas exteriores, los cuales suavizan la estructura creada entre el ángulo recto que forma con el cuerpo principal.

El enorme valor artístico y documental de las piezas señaladas nos obliga a detenernos en ellas mediante de un breve comentario. Comenzaremos con la imagen de crucificado que lo preside, conocido como Padre de Familias. Al respecto, un documento fechado en 1633 revela que fray Payo Afán de Ribera (1613-1684), hermano de sor Ana de la Cruz, regaló a la religiosa esta imagen de crucificado ${ }^{60}$. En opinión de Garramiola Prieto, dicha obra fue «llevada desde Colonia a Méjico por misioneros franciscanos y que fr. Payo Afán de Ribera, obispo de Texaca, envió a su hermana Ana de la Cruz Ribera» ${ }^{61}$. Este fraile, de la orden de San Agustín, hubo de ser un personaje altamente reconocido en su época. Ocupó

56 Torres, 1683:461-462. Aguilar Jurado, A. (1776): Ulía ilustrada y fundación de Montilla. Historia de las dos ciudades, 1776. Montilla: [s.n.], ff. 262r-v. Obra manuscrita.

${ }^{57}$ Ramírez Laguna/Bellido Vela, 2003.

${ }^{58}$ Un estudio más amplio acerca de los bienes artísticos que conserva la capilla del Padre de Familias puede consultarse en: Ramírez Laguna/Bellido Vela: 2003. Bellido Vela, 2006: 23-57.

${ }^{59}$ Hubo de existir un retablo anterior, del tercer cuarto del siglo XVII, dado que Alonso de Torres refiere su existencia. Torres, 1683: 462. Pensamos que el retablo primitivo hubo de presentar trazas barrocas, por lo que cabe la posibilidad que el posterior neoclásico bien suplantó al primero o éste sufrió una serie de modificaciones posteriores que eliminaron los elementos del seiscientos.

${ }^{60}$ Torres, 1683: 461.

${ }^{61}$ Morte Molina, 1982: 81. Garramiola Prieto, 1982: 146-150. 


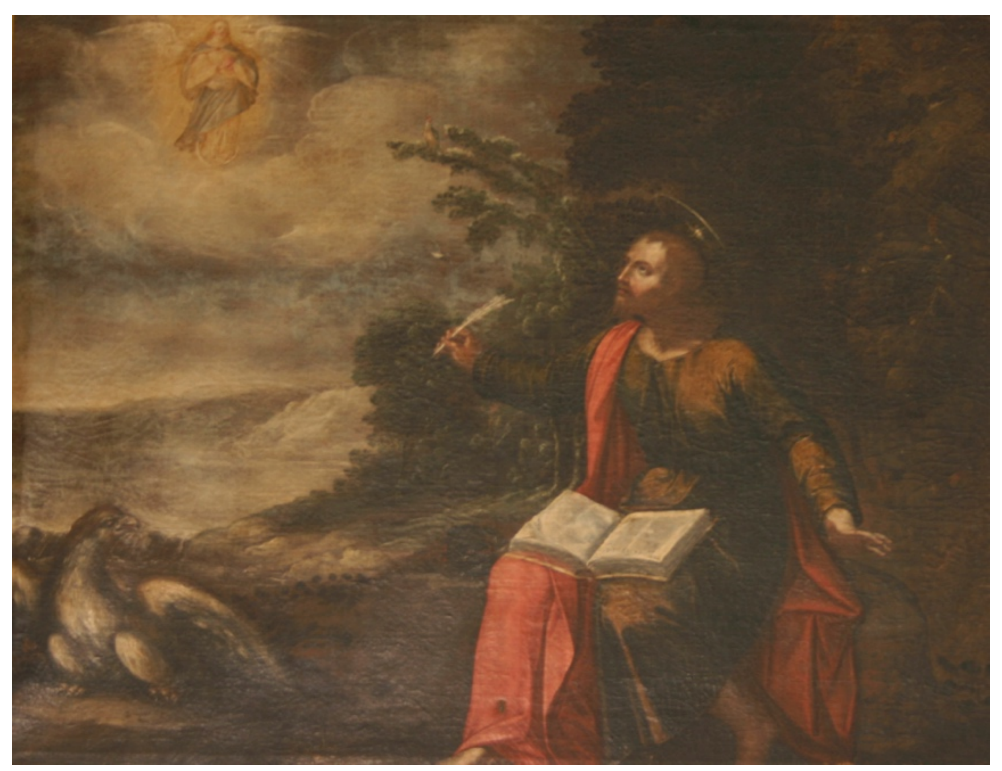

Fig. 7. Anónimo. Visión apocalíptica de san Juan en Patmos. Autora: Elena Bellido Vela.

importantes responsabilidades en el Nuevo Mundo, llegando a ser obispo de Guatemala, arzobispo de México y Virrey de Nueva España. Según el escrito señalado, la referida efigie presidió el Concilio de Trento, aspecto que no se ha podido contrastar con otros documentos ${ }^{62}$.

Sor Ana de la Cruz tuvo una especial devoción a Cristo crucificado. Siempre le rezaba a esta imagen, la cual tuvo delante de su cama mientras estuvo enferma y le habló en repetidas ocasiones, tal y como expresó en sus escritos ${ }^{63}$. Ella misma fue la que le concedió la advocación de Padre de Familias.

El Padre de Familias es obra anónima que, en función de su morfología, puede ser fechada en la segunda mitad del siglo XVI (fig.2). De extraordinaria calidad artística, esta sagrada imagen está realizada en pasta de madera policromada. Pese a sus reducidas dimensiones, llama poderosamente la atención por su realismo. Cristo se halla sujeto a la cruz por tres clavos, revelando una admirable perfección anatómica, que es realzada por una acertada policromía. El rostro, que cae sobre el pecho y hacia la derecha, destaca por el minucioso tratamiento de sus rasgos faciales, con nariz fina y recta, mientras que los ojos se muestran levemente entreabiertos, al igual que la boca. Aunque dispone de una larga cabellera natural, probablemente añadida a finales del siglo XVII en su afán por acentuar cuanto se pudiese el naturalismo de las imágenes sagradas, el Padre de Familias tiene pelo tallado original, como se manifiesta en la barba bífida con mechones enroscados. Las magulladuras de las rodillas, las llagas ocasionadas por los clavos y la lanzada del costado son asimismo tratadas con una gran veracidad. Con respecto al perizoma o paño de pureza hemos de resaltar su destacada sencillez, se dispone cruzado y carece de nudo, simulando pliegues paralelos. Por su parte, la

62 Garramiola Prieto, 1994: 117. El autor facilita la transcripción del documento: «En 30 días de enero de 1633, como yo Juan Díaz de Mora, clérigo, por mandato de E R Señoría Excma. P. mí S. D. Payo Afán de Ribera, religioso del Orden del gran Padre Agustín, obispo de Guatemala y arzobispo de Méjico y gobernador de la Nueva España, hice entrega al convento de mi señora Santa Clara de Montilla de un crucifijo de hechura de talla, de poco más o menos de una vara, habiendo traído consigo los Padres del Concilio de Trento, y este crucifijo presidió el concilio de los Padres de Trento, naciendo Fr. Payo Afán de Ribera, hijo del duque de Alcalá, marqués de Tarifa, grande de de España y de Castilla, comendador de Guerra de la Orden de Santiago, del consejo de guerra de su Majestad, lo remitió a su hermana Ana de Ribera, monja profesa en nuestro convento de mi señora Santa Clara de Montilla, siendo abadesa de él Sor Ángeles López de Mendoza, y para que conste doy fe. Juan Díaz Mora».

63 Torres, 1683: 461; 687. 
cruz actual es de sección rectangular, está realizada en plata cincelada y su superficie despliega una elegante decoración en base a volutas con tallos vegetales entrelazados. El sagrado madero que en un principio portó la imagen del Padre de Familias se custodia en el edículo que recuerda el lugar donde sor Ana de la Cruz pasó su enfermedad.

La devoción que la ejemplar clarisa le profesó pronto fue transmitida a los miembros de la Casa de Aguilar, fervor que está justificado a través de distintas donaciones que los nobles ofrecieron a la venerada imagen. De esta forma, fray Alonso de Torres nos informa que Mariana Fernández de Córdoba, VI marquesa de Priego, le regaló la corona de espinas. Se trata de una pieza de orfebrería de una elevada calidad artística, está realizada en oro y engarzada con esmeraldas y rubíes que evocan formas florales en sus contrastados colores. Por su parte, Pedro de Aragón, esposo de Ana Fernández de Córdoba Figueroa - hija del V marqués de Priego-, que ocupó el cargo de Virrey de Nápoles, obsequió los tres clavos que sujetan al Señor, fundidos en oro y diamantes ${ }^{64}$.

Entre las piezas de mayor calidad que se incluyen en el catálogo de bienes artísticos del convento de Santa Clara se encuentran los bustos-relicario de Santa Apolonia y Santa Cecilia ${ }^{65}$, atribuidos con suficiente solidez argumental a Pedro Roldán (fig.3) (fig.4) ${ }^{66}$. A través de estas obras, que están realizadas en madera tallada y policromada, podemos apreciar el tremendo realismo y la preocupación por la expresividad que persigue el maestro sevillano, características que están perfectamente plasmadas en estas excelentes esculturas.

Por su morfología y estilismo ambas pueden fecharse hacia 1653-1654, etapa de consolidación de la producción de Pedro Roldán, cuando se encontraba residiendo en Montilla para ejecutar las esculturas del altar mayor del monasterio concepcionista de Santa Ana ${ }^{67}$. Por lo tanto, a tenor de la fecha de ejecución podemos pensar que estos bustos relicario ingresaron en el convento de Santa Clara bajo el gobierno de sor Catalina de la Trinidad Fernández de Córdoba, quien hubo de estar al corriente de las novedades estilísticas del momento y de las aportaciones del que es considerado como el escultor más representativo de la Escuela Sevillana durante la segunda mitad del siglo XVII.

Las imágenes de Santa Apolonia y Santa Cecilia comparten similar esquema compositivo. Ambas se presentan en medio cuerpo y disponen en una de sus manos la palma del martirio, estando su pecho horadado para portar sus respectivas reliquias. Su alta calidad está concedida merced a la fuerza realista de sus rostros y el buen hacer de sus ropajes, realzados por sus marcados pliegues y por una primorosa aplicación de la policromía. Pedro Roldán interpreta a la perfección los rostros de las santas mártires romanas que se negaron a renunciar sus creencias cristianas, cuyas miradas se dirigen implorantes al cielo. Santa Apolonia lleva como atributo iconográfico las tenazas que causaron su martirio, que porta en la mano izquierda, mientras que su diestra la acerca hacia el hueco del relicario que perfora su pecho, al tiempo que sostiene la palma martirial. Su rostro infunde una serenidad que contrasta con la expresión de Santa Cecilia, cuyo dramatismo queda intensificado por la herida del cuello y el leve giro de su rostro hacia la derecha, haciéndonos partícipes de su sufrimiento ${ }^{68}$.

\footnotetext{
${ }^{64}$ Torres, 1683:462.

${ }^{65}$ Estas piezas se encuentran en la capilla del Padre de Familias desde el momento en que se consagró, estando ubicadas en el primitivo retablo barroco. Al respecto hay que señalar que es habitual el movimiento de obras artísticas muebles dentro del convento, circunstancia que no han sufrido los bustos relicario de Santa Apolonia y Santa Cecilia, tal y como se constata en: Torres, 1683:462. El cronista no especifica la advocación de sendos bustos, al respecto indica que se trata de «dos medios cuerpos de estatura natural de dos Vírgenes; una de las quales tiene en el pecho una cabeza de las Once mil Vírgenes, y la otra una mandíbula de Santa Polonia». Aguilar Jurado, A. (1776): Ulía ilustrada y fundación de Montilla. Historia de las dos ciudades, 1776. Montilla: [s.n.], ff. 262r-v. Obra manuscrita. Distintos autores han descrito a una de estas imágenes como Santa Dorisuiba, presumiblemente, al confundirla con las reliquias que, de esta santa, también se custodian en la capilla. Véase: Morte Molina: 1982: 81. Garramiola Prieto, 1982: 146. La correcta identificación iconográfica de estos bustosrelicario la encontramos en: Bernier Luque/Nieto Cumplido/Rivas Carmona/López Salamanca, 1993: 219.

66 Roda Peña, 2012: 226-227.

${ }^{67}$ Garramiola, 1982:79. Roda Peña, 2012: 79-80.

68 Roda Peña, 2012: 226-227.
} 


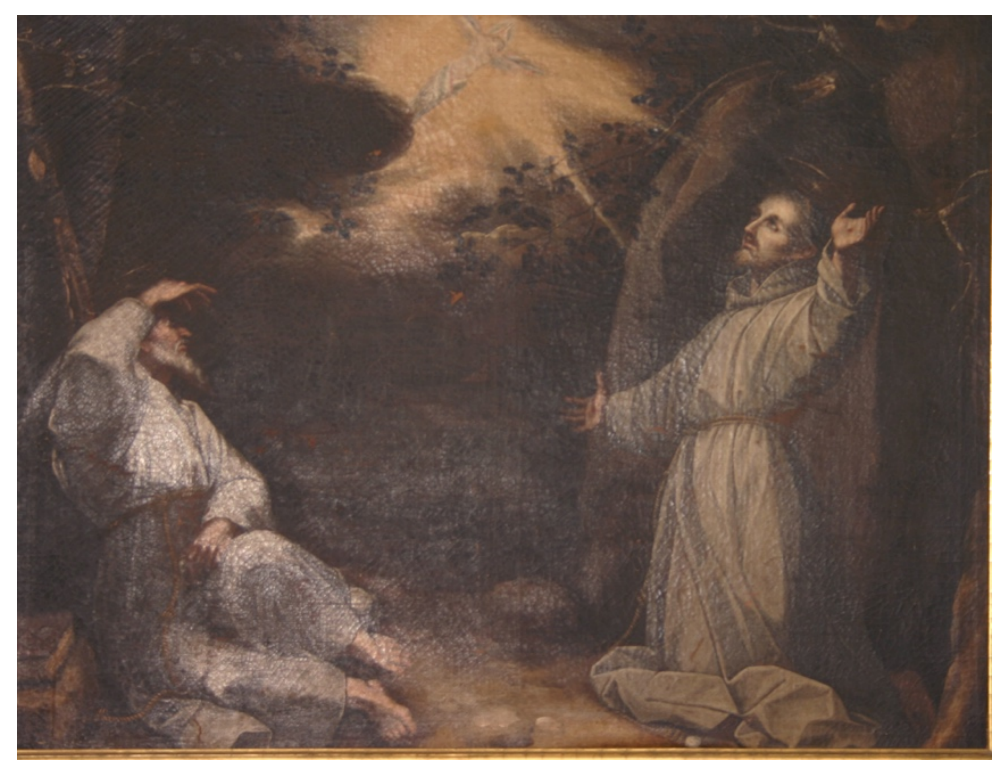

Fig. 8. Anónimo. Estigmatización de San Francisco de Asís. Autora: Elena Bellido Vela.

En esta selección de obras que componen el retablo principal de la capilla del Padre de Familias también nos detendremos en la imagen de la Purísima que culmina en el ático. La defensa del dogma de la Inmaculada Concepción por la orden franciscana determinó que este tema fuese eminentemente difundido en los programas artísticos conventuales. Se trata de una obra anónima que puede datarse a mediados del siglo XVII, efectuada en madera tallada y policromada. Su interpretación iconográfica sigue fielmente las directrices contrarreformistas. María se presenta en pie, sobre un cúmulo de nubes atravesado por una media luna creciente, con las manos unidas en oración. El manto, de un azul intenso, destaca sobre su blanca túnica.

\section{Retratos de sor Ana de la cruz ribera}

Los muros del oratorio acogen dos retratos dedicados a sor Ana de la Cruz Ribera. Estas pinturas fueron ejecutadas tras su óbito, en 1650, puesto que, como gesto de humildad, la religiosa no consintió que la retratasen en vida.

Obra de autor anónimo es el Retrato de sor Ana de la Cruz (fig.5). En este lienzo se la representa de medio cuerpo, ataviada con hábito monjil. Su rostro, que está captado con un tremendo realismo, destaca sobre el fondo oscuro que respalda la composición. Este recurso permite que concentremos toda nuestra atención en su mirada, de expresión serena ${ }^{69}$. Nos mira directamente, ofreciéndonos el madero de la cruz que porta en sus manos, como queriendo invitarnos a que sea nuestro referente a seguir.

Resulta interesante que nos detengamos en ciertos elementos iconográficos que se recogen en este retrato, relacionados con el sentir piadoso de la excelsa clarisa y, a través de los cuales, nos permiten conocer a qué altura espiritual llegó su unión con Dios. Sin duda, el pintor encargado de abordar esta obra hubo de asesorarse minuciosamente acerca de la vida de sor Ana de la Cruz Ribera antes de ejecutarla. En efecto, sobre su pecho aparece una representación del Espíritu Santo, a quien profesó un extraordinario fervor. Ello responde a la interpretación plástica de un arrebato místico que ella sintió, y del que deja constancia en sus escritos informándonos que en más de una ocasión advirtió que su alma era atravesada

${ }^{69}$ Revenga Domínguez, 2016: 130-132. 
por un rayo de fuego que abrazaba su corazón, notando que una paloma estaba dentro de su persona ${ }^{70}$.

Otro detalle que merece la atención en este retrato lo constituye el rompimiento de gloria que aparece en el ángulo superior izquierdo de la composición. Fueron numerosas las visiones de sor Ana de la Cruz en las que Jesucristo sufría los tormentos de la Pasión, tal y como expresó en sus vivencias místicas. Una de las más recurrentes durante los años que soportó su enfermedad es la que denomina como aparición del Virum Dolurum ${ }^{71}$, es decir, Jesús como Varón de Dolores, escena que evoca el episodio inmediato a su crucifixión. Rodeado de un halo luminoso, Cristo ha sido despojado de sus vestiduras y se muestra sedente, en este caso sobre un cúmulo de nubes. Apoya su cabeza, coronada de espinas, en una de sus manos, y de su persona emerge la inscripción VIRUM DOLORVM.

En la franja inferior del lienzo se muestra la leyenda "VENERABILIS MATER ANNA DE LA CRUZ SANCTI ORDINIS FRANCISCANI QUAE AMORI DEI ET PROXIMI CUM EXCELLENTI VITAE PURITATE AC ILUSTRATIONE DIVINAE CONTEMPLATIONIS MAXIME FLORUIT CELEBRIS VIVA ET MORT MIRACULIS ILLUSTRIS. OBIIT MONTULLIE MAGNA SANTITATIS OPINIONIS DIE VENERIS NONIS AUGUSTI. ANNO 1650. AETIS SUA 49 AN".

La segunda pintura dedicada es la titulada Sor Ana de la cruz difunta (fig.6). Dado que esta composición no refleja una firma que delate su autoría, tampoco existe una opinión unánime con respecto a la mano que pudo ejecutarla. De esta forma, algunos autores la atribuyen al pintor montillano José Carbonero, activo durante la primera mitad del siglo XIX ${ }^{\top 2}$. No obstante, Garramiola se decanta por atribuirla a fray Pedro de Valderrama ${ }^{73}$. Cuenta Alonso de Torres que, tras acontecer su fallecimiento, la religiosa fue llevada a la sacristía donde, antes de tomar sepultura, permaneció unas horas con el propósito de retratarla ${ }^{74}$. Es precisamente este momento el que se representa en esta obra. Siguiendo la información del cronista seráfico, la Venerable se muestra en un primer plano, yacente en su lecho de muerte, aspecto que concede un marcado ritmo horizontal a la composición. Sobre fondo oscuro, la religiosa viste hábito de la orden Clarisa, del cual negó desprenderse estando enferma ${ }^{75}$. Sus manos están unidas en oración y portan una sencilla cruz de madera, alusiva a las que milagrosamente pidió la bendición de Jesucristo. Aparece con las piernas entumidas, debido a la parálisis que sufrió. Toda está rociada con jazmines ${ }^{76}$, mientras que sendos cirios encendidos la enmarcan a uno y otro lado.

Pese a que a que en esta composición se detecta cierta rigidez técnica en la representación de la religiosa, especialmente en lo que respecta al tratamiento del pardo hábito, así como a la hora de abordar la recreación espacial, en su contraste se advierte un incipiente naturalismo. Este último aspecto lo encontramos en la toca que cubre sus piernas, de un cuidado plegado, así como en el tratamiento de las manos, que se afanan a la cruz que portan. Asimismo, hemos de considerar la espiritualidad y equilibrio que trasmite el rostro difunto de sor Ana de la Cruz Ribera. Captado de perfil y realzado por el almohadón en el que se apoya, muestra una palidez que, lejos de trasmitirnos turbación, manifiesta la serenidad y paz interior adquirida en su definitiva unión con Dios. En la franja inferior de la pintura se recoge una cartela, fingiendo rocallas de madera, con una inscripción similar al anterior retrato comentado.

70 Torres, 1683: 697-701.

71 Torres, 1683: 688-689.

72 Morte Molina, 1982: 82. Bernier Luque/Nieto Cumplido/Rivas Carmona/López Salamanca, 1993:221. Esta atribución se constata en la cita 96 de la última obra mencionada.

${ }^{73}$ Garramiola: 1994: 32. El autor no justifica esta atribución ni alude a una posible cronología.

74 Torres, 1683:705. Según el autor, este retrato se realizó por la devoción de las religiosas, siendo considerado como el original del cual se han sacado otras muchas copias posteriores.

75 Torres, 1683:696.

76 La presencia de jazmines sobre su cuerpo podría evocar diferentes interpretaciones, como la ceremonia de profesión solemne de las religiosas, que, tendidas en el suelo, le esparcen pétalos de flores, o bien, el hecho de morir en olor de santidad. 


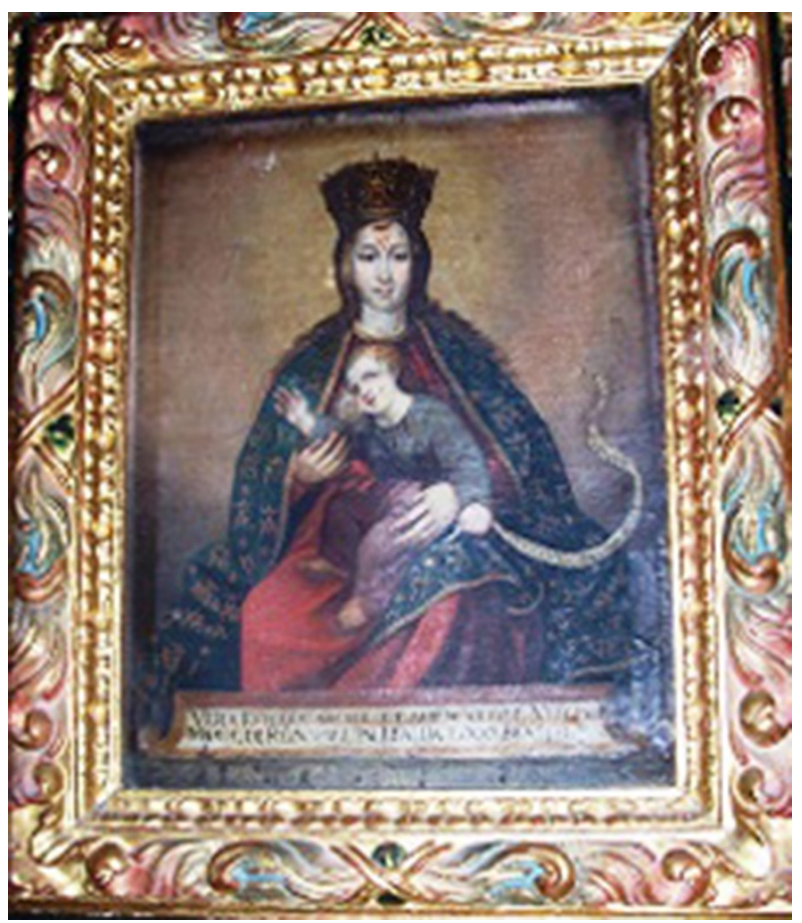

Fig. 9. Anónimo. Virgen con el Niño. Autora: Elena Bellido Vela.

\section{Pinturas devocionales}

La capilla del Padre de Familias custodia un excelente conjunto de pinturas que participan del devocionario de sor Ana de la Cruz, como lo fueron san Francisco de Asís, san Juan Evangelista, san Miguel Arcángel y, por supuesto, María Santísima ${ }^{77}$.

De los años centrales del siglo XVII es la magnífica interpretación de la Visión apocalíptica de San Juan en Patmos (fig.7). Se trata de una obra de autor desconocido que ilustra el tema de la defensa del dogma inmaculista, siguiendo la revelación que san Juan tuvo de la mujer vestida de sol y coronada por doce estrellas. Destaca la marcada diagonal que organiza la composición, estableciendo un acentuado contraste lumínico entre el espacio frondoso — donde san Juan se dispone a narrar la visión apocalíptica-, con el paisaje limpio y resplandeciente donde tiene lugar la aparición mariana. Resulta asimismo interesante detenernos en la calidad de factura que el autor insufla en la figura del evangelista que, en actitud sedente y captado en tres cuartos, muestra una naturalidad y expresividad gestual excepcionales en el momento de presenciar la visión celestial. El conjunto lo completa la presencia del águila, símbolo parlante de san Juan, situado en el ángulo inferior izquierdo.

Formando pareja con la pintura dedicada a la visión de san Juan encontramos una obra que escenifica la Impresión de las llagas a san Francisco de Asís (fig.8). Su factura delata una mano distinta a la anterior, aunque participa de unos parámetros estilísticos que también permiten fecharla en los años centrales del siglo XVII. La escena representada inmortaliza el momento en el que san Francisco de Asís, estando en oración en el Monte Alvernia, es estigmatizado en una visión por el mismísimo Jesucristo en forma de serafín, prodigio que es presenciado por el hermano León. Al igual que la anterior obra comentada, se advierte una composición que está basada en un juego de diagonales, recurso que permite distinguir un enfatizado contraste de luces ocasionado por el refulgir que proyecta la visión celestial en el interior del

\footnotetext{
77 Torres, 1683:684.
} 


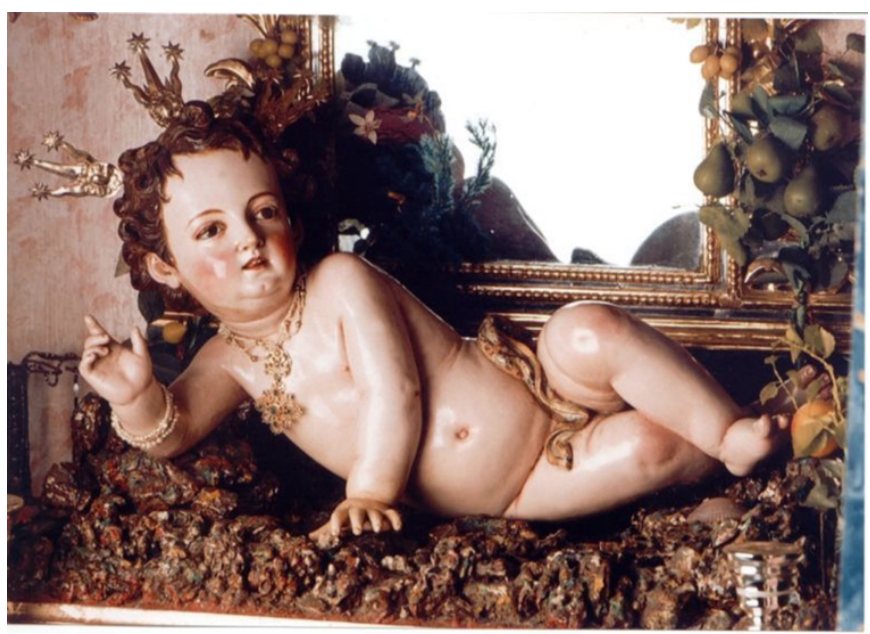

Fig. 10. Anónimo. Niño Jesús Tendidito. Autora: Elena Bellido Vela.

angosto paraje. Los personajes, sumidos en la penumbra, quedan deslumbrados, mostrando un elogioso realismo tanto en sus actitudes como en el tratamiento de las vestimentas.

Otro de los lienzos representativos es el dedicado a San Miguel Arcángel, santo del que sor Ana de la Cruz gozó su aparición en distintas ocasiones. Es obra anónima del siglo XVIII. $\mathrm{Al}$ mando del ejército celestial, san Miguel irrumpe en el momento en el que vence al demonio. Ataviado como guerrero, porta escudo, coraza y espada flamígera desenvainada, su dinámica actitud eleva su capa al viento.

En sus continuas horas de meditación, sor Ana de la Cruz tuvo el privilegio de visionar a María Santísima en numerosas ocasiones, concediéndole reconfortantes palabras que le ayudaron a soportar el dolor de su enfermedad, «Tú Ana, tomaste la Cruz de mi Hijo, y por amor te ha enclavado en ella con sus clavos $\gg^{7}$. Entre las obras pictóricas dedicadas a la Virgen encontramos ejemplares que alcanzan una notable calidad artística, como lo son la Virgen del Pópulo, y la Virgen de la Pa: La primera está datada en el siglo XIX y se atribuye al pintor José Carbonero ${ }^{79}$, mientras que la segunda es una interpretación en menor dimensión de la que actualmente se encuentra en la Basílica de San Juan de Ávila de Montilla.

No obstante, cabe detenernos en la obra Virgen con el Niño (fig.9), que despierta un destacado interés debido a su peculiar iconografía. Se trata de una pintura de autor anónimo que, por su afinidad estética, puede ser fechada y catalogada dentro de la producción italiana del siglo XVI. Responde a una composición muy sencilla, centrada en las imágenes de la Virgen con el Niño, que resaltan sobre un fondo neutro color meloso. María se dispone sedente, de medio cuerpo, viste amplios ropajes y porta sobre su pierna izquierda a Jesús. Aunque se advierta un avance técnico en la configuración de las figuras, también destacan ciertos elementos que responden a una iconografía que revela ciertos resabios medievales. En efecto, la imagen mariana queda captada frontalmente y, con gesto sereno, muestra una herida en su frente de la que desprende unas gotas de sangre que caen sobre el rostro de Jesús. Una leyenda en la parte inferior de la composición escrita en lengua italiana confirma su origen y procedencia ${ }^{80}$.

78 Torres, 1683: 698.

79 Morte Molina, 1982: 82.

${ }^{80}$ Esta interesante obra no aparece recogida en otros estudios que abordan las piezas artísticas de esta capilla. 
Fig. 11. Atribuido Hermanas Cueto. Niño Jesús de las Lagrimitas. Autora: Elena Bellido Vela.

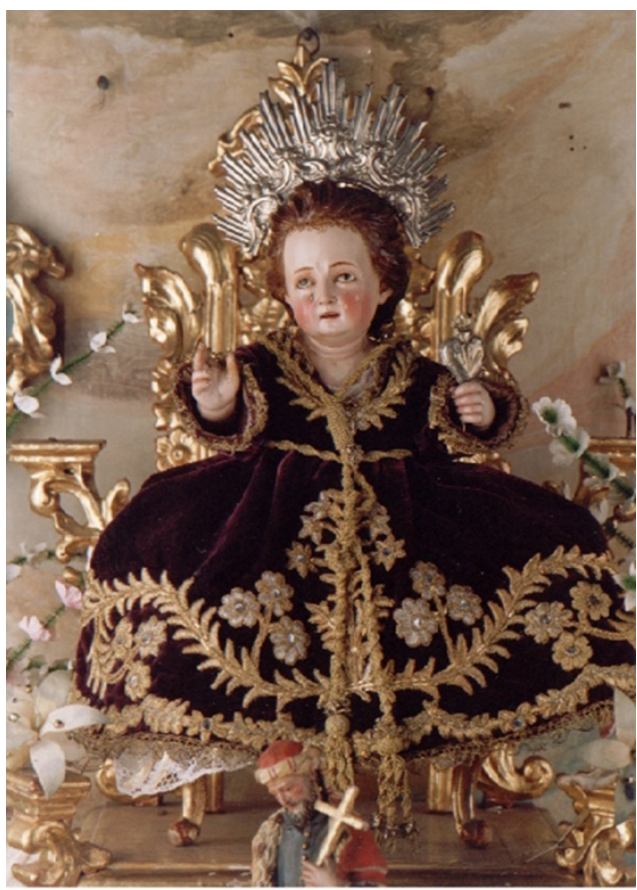

\section{Imágenes del Niño Jesús}

La devoción al Niño Jesús puede remontarse a la figura de san Francisco de Asís, por lo que la Orden la adoptó de forma rápida. Es precisamente durante el Barroco cuando se advierte un auge del culto al Niño, y fue en los conventos femeninos franciscanos donde más se expandió. Muchas de las religiosas que ingresaban en la vida contemplativa aportaban en su dote una imagen del Niño Jesús, quedando en la clausura.

El convento de Santa Clara conserva una excelente colección de imágenes de Niño Jesús. Realizados en su mayoría durante la segunda mitad del siglo XVII y a lo largo del XVIII, la capilla del Padre de Familias acoge algunos ejemplares considerados de factura excepcional. Estas representaciones del Divino Infante poseen distintas actitudes, en su mayoría son de talla completa y están vestidas primorosamente por las religiosas.

La presencia de estas imágenes en la capilla queda justificada en el amor que sor Ana de la Cruz profesó al Niño Dios y en sus continuas apariciones ${ }^{81}$. Este portento aparece plasmado en sus escritos, en los que relata que conversó con Él, como también lo hicieron santa Clara y san Antonio, célebres santos franciscanos.

En función de la actitud mostrada por cada uno de estos niños, podemos realizar una clasificación en dos grupos: aquellos que adoptan un realismo cargado de gracia, dulzura y anecdotismo propios de la infancia, así como los que en su iconografía expresan un contenido más místico y teológico.

Englobado en el primer grupo podemos incluir al Niño Jesús Tendidito (fig.10). Es obra de autor desconocido, realizada en barro cocido y policromado, pudiéndose datar — siguiendo la opinión de López Salamanca- durante la primera mitad del siglo XVIII ${ }^{82}$. Se representa recostado sobre una peana plana que simula un risco, adornado con frutas de cera y caracolas naturales. Esta imagen del Divino Infante trasmite todo el candor e inocencia de la infancia. Nos encandila con su graciosa actitud, haciendo el ademán de bendecirnos con la mano derecha, mientras que la contraria le sirve de apoyo para mantener el equilibrio, al tiempo que mantiene las piernas cruzadas. De excelente calidad artística, en esta obra puede apreciarse una especial habilidad del maestro anónimo en el tratamiento de la anatomía

\footnotetext{
81 Torres, 1683: 693.

82 López Salamanca, 1993: s/f.
} 


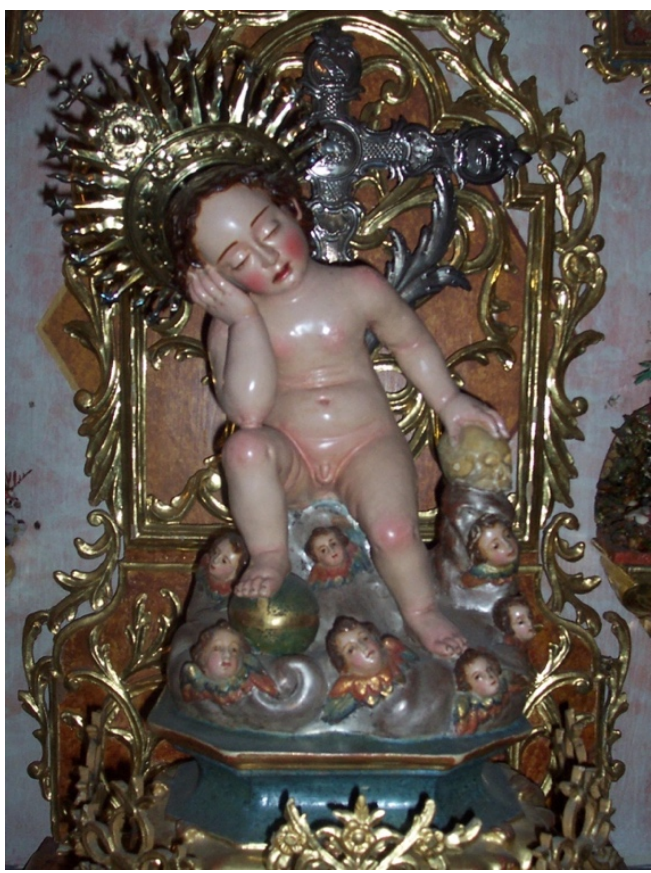

Fig. 12. Anónimo. Niño Jesús Dormido. Autora: Elena Bellido Vela.

infantil y en la captación de la expresión del rostro, de gesto delicado e inocente, así como en la aplicación de una sutil policromía.

Perteneciente a esta línea iconográfica también se puede catalogar el conocido como Niño Jesús de sor Ana de la Cruq. Según la tradición perteneció a la Venerable, aunque por sus características estéticas y morfológicas no podemos afirmarlo con suficiente solidez argumental. Modelado en cera, se muestra acunado en el pesebre, como ella misma constató que se le apareció ${ }^{83}$. Esta obra, que participa del realismo que caracteriza a la imaginería barroca, se custodia alojada en una vitrina rectangular de cristal, con rocalla de madera dorada en su parte superior.

Una actitud muy diferente manifiestan las imágenes de Niño Jesús las cuales atienden a una iconografía que encierra una tendencia más mística. Esta inclinación responde, como indica Mâle, a la influencia que ejercieron las meditaciones de distintos teólogos, en su mayoría franceses de principios del siglo XVII, quienes vieron en la representación del Niño Dios una premonición de los sufrimientos de la Pasión ${ }^{84}$. Es así como se muestra el Niño Jesús de la Lagrimitas (fig. 11), cuyas características morfológicas tienen suficientes afinidades para atribuir esta imagen a las hermanas Cueto, imagineras montillanas cuya existencia transcurrió a mediados del siglo XVIII. El Divino Infante se identifica en esta obra como Niño del Sagrado Corazón, captado en actitud sedente sobre un sillón de madera tallada y dorada al gusto barroco. Está modelado en barro cocido y policromado, expresando en su rostro cierta tristeza, con gesto compungido presiente su Pasión y Muerte. Mientras que con la diestra hace ademán de bendición, con la izquierda nos muestra su corazón, realizado en plata, símbolo de su amor hacia los hombres.

Por su parte, el Niño Jesús Dormido adquiere una acentuada carga teológica, pero al mismo tiempo trasmite un candor infantil que permite su cercanía al devoto, propia del realismo barroco (fig.12). Sedente sobre peana con respaldo de madera tallado y dorado, el Niño Dios se muestra dormido sobre una cruz de plata cincelada. La ausencia de ropas permite calibrar la magnífica calidad en el modelado de esta imagen infantil, que se representa apoyando en la diestra su dulce rostro, mientras que la mano izquierda la deja caer sobre una calavera. Por su parte, la pierna izquierda, que queda flexionada, se apoya sobre el globo terráqueo que

83 Torres, 1683: 693.

84 Mâle, 2001: 299-304. 


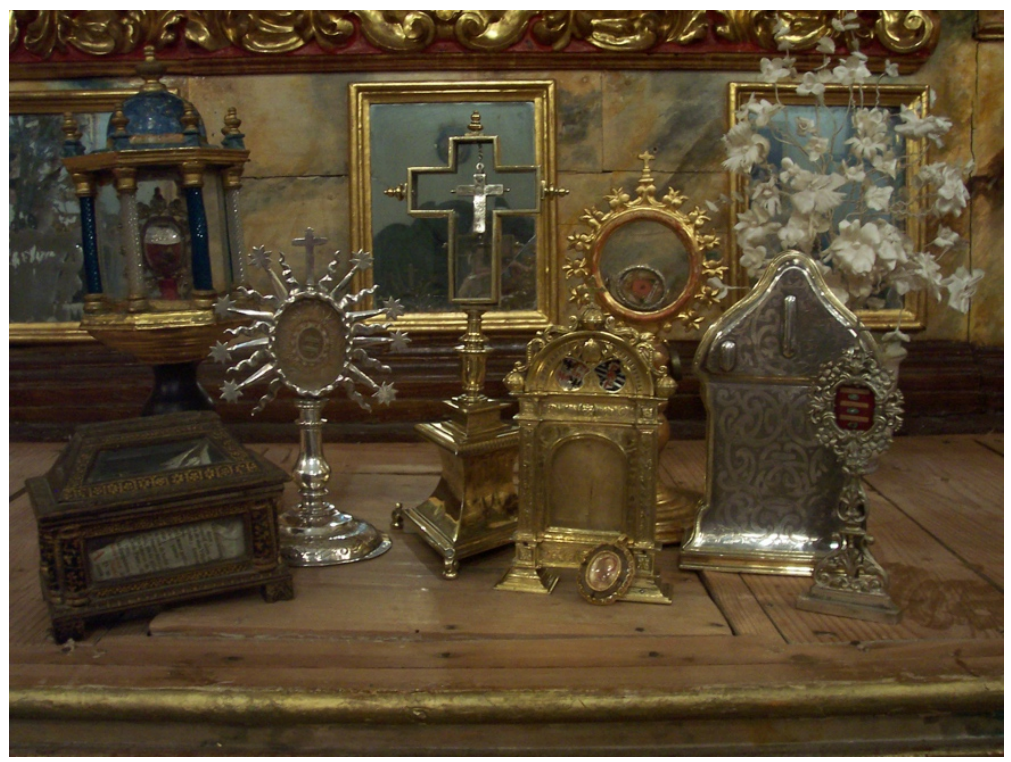

Fig. 13. Reliquias. Autora: Elena Bellido Vela.

emerge de un cúmulo de nubes con querubines. Todo ello responde a la manifestación del triunfo de Jesús sobre la Tierra y sobre la muerte. López Salamanca atribuye su factura a las hermanas Cueto, de mediados del siglo XVIII ${ }^{85}$. De contenido muy similar es la imagen del Niño Jesús Rey. No obstante, en su interpretación porta un báculo de plata dorada, por lo que cabe la posibilidad de que ha sufrido una modificación de atributos iconográficos originales que portaba.

\section{Reliquias}

El carácter protector de las reliquias de los santos ocasionó su veneración desde los primeros años del cristianismo, aspecto que retoma la piedad contrarreformista hasta el punto de convertirse en asunto de debate durante una de las sesiones del Concilio de Trento, en $1563^{86}$. Impulsados por este fervor hacia las reliquias, destacados miembros de la Casa de Aguilar donaron al convento de Santa Clara restos de santos traídos de otras tierras. Aunque en tiempos anteriores a la construcción de la Capilla del Padre de Familias las reliquias se custodiaban en el Coro Alto ${ }^{87}$, posteriormente fueron trasladadas a este recinto, que lo hacen un auténtico oratorio-relicario del cenobio montillano.

El interés de estas piezas le viene concedido tanto por la singularidad de las reliquias en sí, como por la excelencia que posee la factura de sus respectivos relicarios, algunos de los cuales han sido realizados por aventajados orfebres (fig.13).

Excepcional valor documental y artístico ostenta el relicario del Lignum Crucis. El fragmento de la Santa Cruz fue un obsequio que la Emperatriz María de Habsburgo - hija del Emperador Carlos V e Isabel de Portugal- realizó a la Santa Condesa de Feria debido a la admiración que le tenía, haciéndoselo llegar a través de fray Luis de Granada en 1560. Como respuesta, Ana Ponce de León le obsequió con una copia del sermón que san Juan de

\footnotetext{
85 López Salamanca, 1993: s/f. 1564.

${ }^{86}$ López de Ayala, (1847): 328-329. Obra traducida del texto latino corregido según la edición publicada en

87 Torres, 1683:460.
} 
Ávila pronunció el día de su profesión. Esta reliquia, cuyas astillas adquieren el signo de la cruz, iba engarzada en un rosario ${ }^{88}$.

El relicario, en el que no constan marcas de autoría, es de un marcado purismo, acorde con las tendencias artísticas de la segunda mitad del siglo XVI. Está realizado en plata lisa sobredorada y en su color y, en su morfología, dispone de un cuerpo de sección triangular triple decreciente sobre el que emerge un astil balaustrado. El conjunto está coronado por una caja de cristal — con armazón de bronce sobredorado-, que en su forma simula una cruz, custodiando en su interior el Lignum Crucis, el cual pende de una escueta cadena.

Otra de las piezas que alcanzan un destacado lugar en el catálogo de bienes artísticos del convento de Santa Clara es el Relicario de la Santa Espina. Se trata de una extraordinaria pieza de orfebrería que aloja una espina tenida como verdadera de la corona del suplicio de Jesús. Esta reliquia, como indica Alonso de Torres, fue donada al convento, procedente de la catedral de Trento, por Gómez Suárez de Figueroa, conde de Feria, en $1551^{89}$.

El relicario, que no dispone de punzones, está labrado en plata sobredorada y se advierte aplicación de esmaltes. En su configuración sigue el modelo de portapaz y está concebido a modo de capillita, albergando en su hornacina, a modo de arco de medio punto acristalado, la Santa Espina. Sobre pilastras cajeadas, las enjutas de la arcuación están ornamentadas con menudos motivos mitológicos, propios del plateresco, que evidencian el lenguaje humanista de este periodo del primer renacimiento en España. Un frontón curvo culmina el conjunto, centrado por sendos motivos heráldicos que están unidos por una mitra, mientras que su trasdós aparece guarnecido con unas volutas y orbes en sus vértices y clave central, que está coronado por una cruz.

También se custodian en este recinto sagrado los restos de la mártir paleocristiana Santa Dorisuiba. Sus reliquias fueron trasladadas desde Roma por Ana Fernández de Córdoba, hija del $\mathrm{V}$ marqués de Priego ${ }^{90}$. La urna que conserva sus restos es rectangular, elaborada en madera de caoba y acristalada. Sobre un cuerpo troncopiramidal se ubica el escudo nobiliario de los Fernández de Córdoba.

Aunque no se constata documentación fehaciente, popularmente se incluye en el mecenazgo que ejercieron los miembros de la Casa de Aguilar la reliquia de la falange de un dedo de San Sebastián ${ }^{91}$, procedente de la abadía de Montecasino y traída por el Gran Capitán, quien, como manifiesta Garramiola, la donó a su sobrino el primer marqués de Priego ${ }^{92}$.

Interesante es asimismo el relicario que protege los restos del célebre franciscano san Bernardino de Siena. Realizado en plata en su color, presenta rúbrica de punzón de URVANO, pudiéndose datar en los primeros años del siglo XVIII. Esta pieza presenta tipo ostensorio con viril ovalado, desprendiendo en su rededor rayos flameantes y destellos lineales acabados en estrella. Una cruz plana culmina la pieza.

Finalizaremos este recorrido por algunas de las piezas más relevantes que atesora la capilla del Padre de Familias del convento de Santa Clara de Montilla con la reliquia de San Francisco Solano, la cual adquiere una especial significación. Fueron los marqueses de Priego grandes valedores de la santidad del fraile montillano, llegando a hacer juramento y votos al evangelizador de las Indias como patrón de la ciudad de Montilla y del conjunto del marquesado de Priego. Este solemne acto tuvo lugar el 14 de marzo de 1647 en el convento franciscano de San Lorenzo ${ }^{93}$, aunque su canonización fue concedida por el Papa Benedicto XVI en $1726^{94}$. Tallado en madera, el relicario que contiene restos de san Francisco Solano responde al tipo de de farol. Su base es circular concéntrica, sobre la que se alza el astil

${ }^{88}$ Roa, 1615:107. Torres, 1683:461.

89 Torres, 1683: 460-461.

90 Torres, 1683:461.

91 Torres, 1683: 460. Aguilar Jurado, A. (1776): Ulía ilustrada y fundación de Montilla. Historia de las dos ciudades, 1776. Montilla: [s.n.], ff. 262 v. Obra manuscrita.

92 Garramiola, 1982: 150.

93 Torres, 1683: 120.

94 Plandolit, 2010: 189. 
abalaustrado que sostiene un edículo en forma de templete de base octogonal columnado en sus vértices. Todo el conjunto está cubierto por una cúpula hemiesférica.

\section{Conclusiones}

En este trabajo sobre la capilla del Padre de Familias del convento de Santa Clara de Montilla, auspiciada por la fama de santidad adquirida por sor Ana de la Cruz Ribera, se ponen en relieve distintos aspectos. Por un lado la puesta en valor de algunas de sus piezas artísticas más significativas, tanto por su calidad como por la significación que presentan con respecto a su vinculación con la excelsa religiosa. La valoración de estas obras también queda realzada por su desconocimiento, dado que este recinto sagrado se encuentra ubicado en la clausura conventual y su acceso queda restringido al pueblo común ${ }^{95}$.

Asimismo se plantea el mecenazgo ejercido por el marquesado de Priego en el convento clariano que, en este caso, queda representado en la figura de sor Catalina de la Trinidad Fernández de Córdoba, a la sazón abadesa del monasterio y promotora de la capilla que se erigió en homenaje a sor Ana de la Cruz Ribera.

95 Por este motivo quiero hacer constar mi agradecimiento a la comunidad religiosa del convento de Santa Clara de Montilla, sin cuya colaboración y facilidades ofrecidas este trabajo difícilmente se hubiese realizado. 
Bibliografía

Atienza López, A.: Tiempo de conventos. Una historia social de las fundaciones en la España Moderna. Madrid: Marcial Pons. (2008).

Atienza López, A.: "Nobleza, poder señorial y conventos en la España Moderna. La dimensión política de las fundaciones nobiliarias". En: Sarasa, E. / Serrano, E. (eds.) (2010). Estudios sobre señorío y feudalismo: homenaje a Julio Valeón. Zaragoza: Institución Fernando el Católico, (2010), pp. 235-269.

Bellido Vela, E.: "Apuntes iconográficos de la capilla del Padre de Familias del convento de Santa Clara de Montilla". En: Peláez del Rosal M. (ed.) (2006): X Curso de Verano el Franciscanismo en Andalucía. Clarisas, Concepcionistas y Terciarias Regulares. Córdoba: Asociación Hispánica de Estudios Franciscanos, (2006), pp. 23-57.

Bellido Vela, E.: "Sor Catalina Margarita de la Trinidad Fernández de Córdoba (1613-1676), abadesa de Santa Clara de Montilla y mecenas de las artes”. En: Peláez del Rosal M. (ed.) (2009): XIV Curso de Verano El Franciscanismo en Andalucía.Perfiles y figuras del Franciscanismo andaluz: Córdoba: El Almendro, 2009, (2009), pp. 41-57.

Bernier Luque, J./Nieto Cumplido, M/Rivas Carmona, J./ López Salamanca, F.: Catálogo artístico y monumental de la provincia de Córdoba. Córdoba: Junta de Andalucía, Diputación y Caja Provincial de Ahorros, tomo VI. (1993), pp. 187-225.

Calvo Poyato, J.: Guía Histórica de Montilla. Córdoba: Excma. Diputación Provincial de Córdoba. Excmo. Ayuntamiento de Montilla. (1987).

Fernández de Bethencourt, F.: Historia Genealógica y Heráldica de la Monarquía Española, Casa Real y Grandes de España, tomo VI. Madrid: Establecimiento Tipográfico de Enrique Teodoro. (1905).

Fernández de Córdoba, F. (1954): Historia y descripción de la antigüedad y descendencia de la Casa de Córdoba. Córdoba: Real Academia de Córdoba de Ciencias, Bellas Letras y Nobles Artes.

Garramiola Prieto, E.: Montilla, guía histórica, artística y cultural de esta ciudad. Córdoba: El Almendro. (1982).

Garramiola Prieto, E.: La noche oscura de Ana de la Cruz Ribera en Santa Clara de Montilla. Montilla: Comisión del VIII Centenario de la muerte de Santa Clara. (1994).

Graña Cid. M.M.: "Políticas nobiliarias femeninas y espiritualidad en la primera Edad Moderna: Santa Clara de Montilla”. En: Verdady Vida, 258/LXI, Madrid, (2011), pp. 149177.

López de Ayala, I. (trad.): El Sacrosanto y Ecuménico Concilio de Trento. Barcelona: Imprenta de Ramón Martín Indar. (1847).

López Salamanca, F.: Catálogo de obras de arte y enseres del convento de Santa Clara de Montilla. Montilla: Ayuntamiento de Montilla. (1993).

López Torrijos, R.: La mitología en la Pintura Española del Siglo de Oro. Madrid: Cátedra. (1985).

Lleó Cañal, V.: Nueva Roma: mitología y humanismo en el Renacimiento Sevillano. Sevilla: Diputación Provincial de Sevilla. (1979).

Mâle, E. (2001): El arte religioso de la Contrarreforma. Madrid: Destino.

Matute y Gaviria, J.: Anales eclesiásticos y seculares de la M.N.Y M.L. Ciudad de Sevilla, tomo, I. Sevilla: Guadalquivir. (1997).

Morte Molina, J.: Montilla. Apuntes históricos de esta ciudad. Montilla: Ayuntamiento de Montilla Asociación de Antiguos Alumnos Salesianos. (1982).

Plandolit, L. J.: El Apóstol de América San Francisco Solano. Córdoba: Diputación Provincial de Córdoba. (2010).

Ramírez Laguna, A./ Bellido Vela, E.: Documentación y catalogación para la inclusión en el Catálogo General de Patrimonio Histórico Andaluz del Conjunto Monumental formado por el Convento de Santa Clara y el Palacio Ducal de Medinaceli de Montilla Córdoba. Inédito. (2003).

Revenga Domínguez, P.: "Artificio, elocuencia expresiva y percepción visual: el protagonismo de la luz en la pintura barroca". En: Sáenz González, O. (coord.) (2016): 
Palas y las Musas. Diálogos entre la ciencia y el Arte, II, Barroco. México: Siglo XXI Editores, (2016), pp. 125-158.

Ribera, P.: Tratado en el que se defienden nueve proposiciones en que la V. M. Ana de la Cruz, Religiosa en el observantísimo Convento de Santa Clara de la ciudad de Montilla dejó propuestas las gracias que dijo haberse servido N. Señor Jesucristo de conceder unas Cruces, afirmando que Su Majestad Divina se dignó de dar a dichas Cruces su sagrada bendición. México: Viuda de Bernardo Calderón. (1679).

Roa, M. De : Vida de doña Ana Ponce de León Condesa de Feria, Monja en Santa Clara de Montilla. Sevilla: Alonso Rodríguez Gamarra. (1615).

Roda Peña, J.: Pedro Roldán. Madrid: Arco/Libros. (2012).

Rodríguez de Gracia, H.: "Análisis económico de los conventos de Santa Ana y Santa Clara de Montilla a mediados del siglo XVIII". En: [s.n.] (1988): Montilla: Historia, Arte y Literatura. Homenaje a Manuel Ruiz Luque. Baena: Adisur, (1988), pp. 233-276.

Torres, Alonso de,: Crónica de la provincia Franciscana de Granada. Madrid: Imprenta de Juan Infançon. (1683).

Triviño Monraval, M. V.: Escritos de Sor Ana de la Cruz Ribera 1606-01650, clarisa en el convento de Santa Clara de Montilla. Montilla: Bibliofilia Montillana. (1994).

Triviño Monraval, M. V.: "Escritoras franciscanas hispanas". En: Graña Cid, M. M. (ed.) (2005). El franciscanismo en la Península Ibérica. Balance y Perspectivas. Barcelona: Asociación Hispánica de Estudios Franciscanos, (2005), pp. 101-124.

Valdivieso González, E.: Historia de la Pintura Sevillana. Sevilla: Guadalquivir. (1992). 